\title{
Transcriptional adaptations following exercise in Thoroughbred horse skeletal muscle highlights molecular mechanisms that lead to muscle hypertrophy
}

\author{
Beatrice A McGivney ${ }^{1}$, Suzanne S Eivers ${ }^{1}$, David E MacHugh ${ }^{1,2}$, \\ James N MacLeod ${ }^{3}$, Grace M O'Gorman ${ }^{1}$, Stephen DE Park ${ }^{1}$, Lisa M Katz ${ }^{4}$ \\ and Emmeline W Hill*1
}

Address: ${ }^{1}$ Animal Genomics Laboratory, UCD School of Agriculture, Food Science and Veterinary Medicine, UCD College of Life Sciences, University College Dublin, Belfield, Dublin 4, Ireland, ${ }^{2}$ UCD Conway Institute of Biomolecular and Biomedical Research, University College Dublin, Belfield, Dublin 4, Ireland, ${ }^{3}$ Gluck Equine Research Center, Department of Veterinary Science, University of Kentucky, Lexington, KY 40546-0099, USA and ${ }^{4}$ University Veterinary Hospital, UCD School of Agriculture, Food Science and Veterinary Medicine, UCD College of Life Sciences, University College Dublin, Belfield, Dublin 4, Ireland

Email: Beatrice A McGivney - Beatrice.McGivney@ucd.ie; Suzanne S Eivers - Suzanne.Eivers@ucd.ie;

David E MacHugh - David.MacHugh@ucd.ie; James N MacLeod - jnmacleod@uky.edu; Grace M O'Gorman -Grace.OGorman@ucd.ie;

Stephen DE Park - Stephen.Park@ucd.ie; Lisa M Katz - Lisa.Katz@ucd.ie; Emmeline W Hill* - Emmeline.Hill@ucd.ie

* Corresponding author

Published: 30 December 2009

BMC Genomics 2009, 10:638 doi:10.1186/147|-2164-10-638
Received: 25 June 2009

Accepted: 30 December 2009

This article is available from: http://www.biomedcentral.com//47I-2/64//0/638

(c) 2009 McGivney et al; licensee BioMed Central Ltd.

This is an Open Access article distributed under the terms of the Creative Commons Attribution License (http://creativecommons.org/licenses/by/2.0), which permits unrestricted use, distribution, and reproduction in any medium, provided the original work is properly cited.

\begin{abstract}
Background: Selection for exercise-adapted phenotypes in the Thoroughbred racehorse has provided a valuable model system to understand molecular responses to exercise in skeletal muscle. Exercise stimulates immediate early molecular responses as well as delayed responses during recovery, resulting in a return to homeostasis and enabling long term adaptation. Global mRNA expression during the immediate-response period has not previously been reported in skeletal muscle following exercise in any species. Also, global gene expression changes in equine skeletal muscle following exercise have not been reported. Therefore, to identify novel genes and key regulatory pathways responsible for exercise adaptation we have used equine-specific cDNA microarrays to examine global mRNA expression in skeletal muscle from a cohort of Thoroughbred horses $(n=8)$ at three time points (before exercise, immediately post-exercise, and four hours post-exercise) following a single bout of treadmill exercise.

Results: Skeletal muscle biopsies were taken from the gluteus medius before $\left(T_{0}\right)$, immediately after $\left(T_{1}\right)$ and four hours after $\left(T_{2}\right)$ exercise. Statistically significant differences in mRNA abundance between time points $\left(T_{0} v s T_{1}\right.$ and $\left.T_{0} v s T_{2}\right)$ were determined using the empirical Bayes moderated $t$-test in the Bioconductor package Linear Models for Microarray Data (LIMMA) and the expression of a select panel of genes was validated using real time quantitative reverse transcription PCR (qRT$P C R)$. While only two genes had increased expression at $T_{1}(P<0.05)$, by $T_{2} 932$ genes had increased $(P<0.05)$ and 562 genes had decreased expression $(P<0.05)$. Functional analysis of genes differentially expressed during the recovery phase $\left(T_{2}\right)$ revealed an over-representation of genes localized to the actin cytoskeleton and with functions in the MAPK signalling, focal adhesion, insulin signalling, mTOR signaling, $p 53$ signaling and Type II diabetes mellitus pathways. At $T_{1}$, using a less stringent statistical approach, we observed an over-representation of genes involved in the stress
\end{abstract}


response, metabolism and intracellular signaling. These findings suggest that protein synthesis, mechanosensation and muscle remodeling contribute to skeletal muscle adaptation towards improved integrity and hypertrophy.

Conclusions: This is the first study to characterize global mRNA expression profiles in equine skeletal muscle using an equine-specific microarray platform. Here we reveal novel genes and mechanisms that are temporally expressed following exercise providing new knowledge about the early and late molecular responses to exercise in the equine skeletal muscle transcriptome.

\section{Background}

The Thoroughbred racehorse is an elite athlete, that for four hundred years has been selected for physiological traits enabling exceptional speed and stamina. As a highly adapted athlete the Thoroughbred is a suitable model for understanding the physiology of exercise [1]. Thoroughbreds have a very high aerobic capacity or maximal oxygen uptake $\left(\mathrm{VO}_{2 \max }\right)$ [2] relative to their body mass. A bout of intense exercise requires both aerobic and anaerobic energy production and a Thoroughbred may increase its metabolic rate from basal levels by up to 60 -fold under racing conditions [3]. A critical component for athletic performance is muscle and it is notable that the Thoroughbred has a high skeletal muscle mass comprising over $55 \%$ of total body mass [4].

The biological importance of skeletal muscle is reflected in its remarkable structural and functional plasticity that enables rapid alterations to phenotype following repeated bouts of exercise [5]. A single bout of acute exercise induces multiple stresses in skeletal muscle, including increased demand for ATP and mechanical stress $[6,7]$. The responses to these stressors can be divided into two broad categories: the return to homeostasis, and the adaptive response. The principle processes associated with homeostatic recovery are glucose sparing, elevated fat oxidation, glycogen resynthesis and free radical quenching, as well as the repairing of free radical-mediated damage and restoration of intracellular electrolyte concentrations and $\mathrm{pH}$ [8-12]. The adaptive response is the process whereby skeletal muscle responds to repeated exercise bouts (conditioning or training) in ways that cumulatively lead to an enhanced ability to maintain muscle homeostasis during exercise. This conditioning response involves both morphological changes, such as hypertrophy, and metabolic responses such as an increased capacity for oxidative substrate metabolism in mitochondria and a shift toward oxidizing proportionately more fats and less glucose during exercise $[13,14]$.

Exercise studies using human subjects have demonstrated that changes in the expression of a wide range of mRNA transcripts play a major role in the adaptive response of muscle to exercise [15-18]. Furthermore, microarray stud- ies have shown that a large number of genes are differentially expressed in skeletal muscle following exercise [19]. A single bout of exercise has been shown to increase mRNA expression particularly in genes involved in mitochondrial biogenesis and metabolism [20].

While protein changes and mRNA quantified in small panels of genes by Western blotting and real time qRTPCR [21-24] have been investigated, global mRNA expression during the immediate-response period ( $<8$ minutes) has not, to our knowledge, previously been reported in skeletal muscle following exercise in any species. Also, global gene expression changes in equine skeletal muscle following exercise have not been reported. Therefore to identify novel genes and key regulatory pathways responsible for exercise adaptation we have used equine-specific cDNA microarrays to examine global mRNA expression in skeletal muscle from a cohort of Thoroughbred horses $(n$ $=8$ ) at two time points (immediately, and four hours post-exercise) following a standardised incremental-step exercise test on a high-speed equine treadmill.

\section{Results and Discussion Experiment overview}

Eight four-year old unconditioned Thoroughbred horses (castrated males) were exercised to maximum heart-rate or fatigue in a standardized incremental-step exercise test [25-27] on a high-speed equine treadmill. Skeletal muscle biopsy samples were collected at three time points: at rest pre-exercise $\left(T_{0}\right)$, immediately post-exercise $\left(T_{1}\right)$ and four hours post-exercise $\left(T_{2}\right)$. In a direct comparison microarray experiment, equine cDNA microarrays were hybridised with samples from $T_{0} V s T_{1}$ and from $T_{0} V s T_{2}$ for each animal.

\section{Exercise parameters}

Following warm-up, the exercise test comprised an average of six (range 5 - 7) incremental steps achieving a mean maximum velocity of $12.4 \pm 0.2 \mathrm{~m} / \mathrm{s}$ and a mean distance of $4,362.9 \pm 102.7 \mathrm{~m}$ for an average duration of $8.77 \pm 0.5$ min. Mean maximal heart rate was $218 \pm 9$ beats per minute. Mean peak post-exercise $\left(\mathrm{T}_{1}\right)$ lactate concentrations were $13.3 \pm 1.2 \mathrm{mmol} / \mathrm{l}$ and were significantly increased compared to pre-exercise values $(P<0.0001)$. 


\section{Microarray annotation and gene ontology}

Of the 9,333 ESTs on the microarray 8,519 aligned to a single location on the equine genome (EquCab 2.0), 372 aligned to more than one location and the remaining 442 failed to align to any location with high confidence. Fewer than $50 \%(4,631)$ of the ESTs matched an Ensembl gene, the majority $(4,166)$ of which had human orthologs. The human orthologs were used to create input files for gene ontology functional analyses using the DAVID software package $[28,29]$.

The functional representation of ESTs on the microarray relative to all genes in the Equus caballus Ensembl database that had human orthologs (66\%) was assessed using 15 broad GO categories (developmental process, multicellular organismal process, biological regulation, metabolic process, cellular process, macromolecular complex, organelle part, organelle, cell part, cell, transporter activity, transcription regulator activity, molecular transducer activity, catalytic activity, binding). A similar distribution pattern among GO categories was observed for ESTs on the microarray when compared to all Ensembl genes (Additional file 1).

\section{Immediate response to exercise}

Differential expression of genes

Immediately following exercise $\left(\mathrm{T}_{1}\right)$ two probes were significantly $(P<0.05)$ differentially regulated. Four hours $\left(\mathrm{T}_{2}\right)$ after exercise 1,485 probes were differentially expressed with fold changes ranging from +4.8 -fold to 2.9-fold. At $\mathrm{T}_{2}, 923$ probes were up-regulated and 562 probes were down-regulated. At the chosen significance threshold ( $\alpha=0.05) 74$ of these probes are likely to be false positives. The probes with the greatest changes in expression $(>+1.5$-fold) immediately post-exercise are shown in Table 1 . The probes with the greatest changes in expression $(>+1.5$-fold or -1.5 -fold) four hours post exer- cise are shown in Table 2 (up-regulated) and Table 3 (down-regulated). A full list of gene expression changes at $\mathrm{T}_{1}$ and $\mathrm{T}_{2}$ are available in additional files 2 and 3 . The equine cDNA microarray expression data generated was deposited in the NCBI Gene Expression Omnibus (GEO) repository with experiment series accession [GEO:GSE16235].

Among the probes with the greatest expression changes (> +1.5 -fold) at T1were seven probes representing four genes: three probes representing FOS (v-fos FBJ murine osteosarcoma viral oncogene homolog gene; mean +1.9fold, unadjusted $\mathrm{P}=0.004,0.003,0.039)$; two probes representing HSPA1A (heat shock $70 \mathrm{kDa}$ protein $1 \mathrm{~A}$ gene; mean +2.7 -fold, unadjusted $P=1.50 \mathrm{E}-07,2.42 \mathrm{E}-05$ ); one probe located $\sim 2 \mathrm{~kb}$ upstream of PFKFB3 (6-phosphofructo-2-kinase/fructose-2,6-biphosphatase 3 gene; +2.0fold, unadjusted $\mathrm{P}=4.71 \mathrm{E}-06$ ) and one probe representing EGR1 (early growth response 1 gene; +1.6-fold, unadjusted $\mathrm{P}=0.014)$.

The gene expression changes observed for the FOS and HSPA1A genes are consistent with previous mammalian studies that have shown increased expression of these genes in response to exercise [24,30]. HSPA1A, FOS and EGR1 are members of the immediate-early response (IER) gene family. These genes are early regulators of cell growth and differentiation signals, and are induced in response to a wide variety of stress stimuli [31]. The heat shock protein Hsp70, encoded by the HSPA1A gene, is known to protect skeletal muscle cells against the path physiological effects of oxidative stress. In transgenic mouse models this cytoprotection is brought about both through improvement in muscle function and decreased apoptosis [32-34]. It has been suggested that the cytoprotective effects of the Hsp70 protein are related to an ability to assist with the refolding of denatured or partially degraded proteins [35].

Table I: Genes $\geq+$ I.5-fold (up-regulated) differential expression immediately post-exercise compared to pre-exercise levels.

\begin{tabular}{|c|c|c|c|c|c|c|}
\hline Gene Symbol & Gene Name & GenBank ID & Fold change & $P$ & $\operatorname{adj} P$ & Annotation \\
\hline HSPAIA & Heat shock $70 \mathrm{kDa}$ protein IA & CX60257I & 3.11 & I.50E-07 & 0.001 & EquCab \\
\hline HSPAIA & Heat shock $70 \mathrm{kDa}$ protein IA & CX600510 & 2.15 & $2.42 \mathrm{E}-05$ & 0.080 & EquCab \\
\hline FOS & $\begin{array}{l}\text { v-fos FBJ murine osteosarcoma viral } \\
\text { oncogene homolog }\end{array}$ & CX597113 & 2.13 & 0.004 & 0.997 & chr24:20,679,377-20,68I,089 \\
\hline PFKFB3 & $\begin{array}{l}\text { 6-phosphofructo-2-kinase/fructose-2,6- } \\
\text { bisphosphatase }\end{array}$ & CX594334 & 1.96 & 4.7IE-06 & 0.023 & chr29:27,672,694-27,678,3।4 \\
\hline FOS & $\begin{array}{l}\text { v-fos FBJ murine osteosarcoma viral } \\
\text { oncogene homolog }\end{array}$ & CX604427 & 1.87 & 0.003 & 0.997 & H. Sapien \\
\hline FOS & $\begin{array}{l}\text { v-fos FBJ murine osteosarcoma viral } \\
\text { oncogene homolog }\end{array}$ & CX59236I & 1.59 & 0.039 & 0.997 & H. Sapien \\
\hline EGRI & early growth response I & CX602573 & 1.55 & 0.014 & 0.997 & H. Sapien \\
\hline
\end{tabular}

The gene names provided are either HUGO approved or Equus caballus specific.

Adj $P$ is the $P$-value following adjustment for multiple testing.

Predicted gene annotations were assigned to unannotated probes of interest based on the gene located closest to the probe and homology to mammalian genes, chromosomal locations are provided for these genes. 
Table 2: Genes $\geq+1.5$-fold (up-regulated) differential expression four hours post-exercise compared to pre-exercise levels.

\begin{tabular}{|c|c|c|c|}
\hline Gene Symbol & Gene Name & Fold change & adj $P$ \\
\hline HSPAIA & heat shock $70 \mathrm{kDa}$ protein IA & 4.84 & I.6IE-05 \\
\hline HSP9OAAI & heat shock protein $90 \mathrm{kDa}$ alpha (cytosolic), class A member I & 2.20 & 0.002 \\
\hline USP36 & ubiquitin specific peptidase 36 & 2.17 & 0.001 \\
\hline VWCE & von Willebrand factor $\mathrm{C}$ and EGF domains & 2.07 & 0.001 \\
\hline CCDC6 & coiled-coil domain containing 6 & 1.91 & 0.003 \\
\hline HSP9OAAI & heat shock protein 90 kDa alpha (cytosolic), class A member I & 1.88 & 0.003 \\
\hline NFIC & nuclear factor I/C (CCAAT-binding transcription factor) & 1.85 & 0.003 \\
\hline RCSDI & RCSD domain containing I & 1.80 & 0.001 \\
\hline SEPT9 & septin 9 & 1.75 & 0.005 \\
\hline TMEM / 45 & transmembrane protein 145 & 1.71 & 0.002 \\
\hline BAIAP2 & BAII-associated protein 2 & 1.70 & 0.001 \\
\hline ATXN2L & ataxin 2-like & 1.70 & 0.003 \\
\hline NUCB I & nucleobindin I & 1.67 & 0.004 \\
\hline HSPA8 & heat shock $70 \mathrm{kDa}$ protein 8 & 1.67 & 0.005 \\
\hline STRN4 & striatin, calmodulin binding protein 4 & 1.66 & 0.006 \\
\hline PKM2 & pyruvate kinase, muscle & 1.66 & 0.001 \\
\hline DLX5 & distal-less homeobox 5 & 1.66 & 0.003 \\
\hline CRTC2 & CREB regulated transcription coactivator 2 & 1.66 & 0.002 \\
\hline C20orfl I 2 & uncharacterised protein & 1.64 & 0.001 \\
\hline LAMP2 & lysosomal-associated membrane protein 2 & 1.64 & 0.003 \\
\hline EIFI & eukaryotic translation initiation factor I & 1.64 & 0.018 \\
\hline PKM2 & pyruvate kinase, muscle & 1.63 & 0.028 \\
\hline PLODI & procollagen-lysine I, 2-oxoglutarate 5-dioxygenase I & 1.63 & 0.003 \\
\hline EML3 & echinoderm microtubule associated protein like 3 & 1.62 & 0.006 \\
\hline $\mathrm{Cl} 4$ orf43 & uncharacterised protein & 1.61 & 0.016 \\
\hline PDCD6IP & programmed cell death 6 interacting protein & 1.61 & 0.001 \\
\hline OGFR & opioid growth factor receptor & 1.61 & 0.003 \\
\hline EMP3 & epithelial membrane protein 3 & 1.61 & 0.006 \\
\hline DRAPI & DRI-associated protein I (negative cofactor 2 alpha) & 1.61 & 0.001 \\
\hline Cl4orfl5I. & uncharacterised protein & 1.59 & 0.004 \\
\hline C20orf29 & uncharacterised protein & 1.59 & 0.001 \\
\hline TUBB & tubulin, beta & 1.58 & 0.001 \\
\hline RNFI9B & ring finger protein $19 \mathrm{~B}$ & 1.58 & 0.017 \\
\hline RCN3 & reticulocalbin 3, EF-hand calcium binding domain & 1.58 & 0.004 \\
\hline PRELP & proline/arginine-rich end leucine-rich repeat protein & 1.58 & 0.012 \\
\hline PEXI6 & peroxisomal biogenesis factor 16 & 1.58 & 0.003 \\
\hline NR4AI & nuclear receptor subfamily 4 , group $A$, member I & 1.58 & 0.006 \\
\hline FTHI & ferritin, heavy polypeptide I & 1.58 & 0.004 \\
\hline CRTC2 & CREB regulated transcription coactivator 2 & 1.58 & 0.004 \\
\hline SUZI 2 & suppressor of zeste 12 homolog (Drosophila) & 1.57 & 0.001 \\
\hline SF3B5 & splicing factor $3 \mathrm{~b}$, subunit $5,10 \mathrm{kDa}$ & 1.57 & 0.003 \\
\hline $\mathrm{SLCI} 6 \mathrm{A3}$ & solute carrier family 16, member 3 (monocarboxylic acid transporter 4 ) & 1.57 & 0.017 \\
\hline PKM2 & pyruvate kinase, muscle & 1.57 & 0.006 \\
\hline DNAJCl & Dnaj (Hsp40) homolog, subfamily C, member I & 1.57 & 0.002 \\
\hline DLX5 & distal-less homeobox 5 & 1.57 & 0.004 \\
\hline DCHSI & dachsous I (Drosophila) & 1.57 & 0.002 \\
\hline SIPAILI & signal-induced proliferation-associated I like I & 1.56 & 0.014 \\
\hline SNAII & snail homolog I (Drosophila) & 1.55 & 0.006 \\
\hline PRKCSH & protein kinase $\mathrm{C}$ substrate $80 \mathrm{~K}-\mathrm{H}$ & 1.55 & 0.007 \\
\hline LCN2 & lipocalin 2 & 1.55 & 0.002 \\
\hline HOXA5 & homeobox A5 & 1.55 & 0.004 \\
\hline KDELRI & KDEL (Lys-Asp-Glu-Leu) endoplasmic reticulum protein retention receptor I & 1.54 & 0.006 \\
\hline IDH2 & isocitrate dehydrogenase 2 (NADP+), mitochondrial & 1.54 & 0.011 \\
\hline AUPI & ancient ubiquitous protein I & 1.54 & 0.048 \\
\hline$S L C I 6 A / 3$ & solute carrier family 16, member 13 (monocarboxylic acid transporter 13) & 1.53 & 0.008 \\
\hline NINJI & ninjurin I & 1.53 & 0.003 \\
\hline HMOX2 & heme oxygenase (decycling) 2 & 1.53 & 0.020 \\
\hline HSP9OAAI & heat shock protein $90 \mathrm{kDa}$ alpha (cytosolic), class A member I & 1.53 & 0.049 \\
\hline CCDCI2 & coiled-coil domain containing 12 & 1.53 & 0.011 \\
\hline
\end{tabular}


Table 2: Genes $\geq+1.5$-fold (up-regulated) differential expression four hours post-exercise compared to pre-exercise levels. (Continued)

\begin{tabular}{|c|c|c|c|}
\hline ARHGEFI9 & Rho guanine nucleotide exchange factor (GEF) 19 & 1.52 & 0.002 \\
\hline NAGPA & $\mathrm{N}$-acetylglucosamine-I-phosphodiester alpha- $\mathrm{N}$-acetylglucosaminidase & 1.52 & 0.005 \\
\hline PTTGIIP & pituitary tumor-transforming I interacting protein & 1.51 & 0.014 \\
\hline NRIDI & nuclear receptor subfamily I, group $D$, member I & 1.51 & 0.020 \\
\hline CLSTNI & calsyntenin I & 1.51 & 0.002 \\
\hline BAIAP2 & BAll-associated protein 2 & 1.51 & 0.005 \\
\hline ATF4 & activating transcription factor 4 (tax-responsive enhancer element B67) & 1.51 & 0.005 \\
\hline $\mathrm{Cl}$ lorf24 & uncharacterised protein & 1.50 & 0.005 \\
\hline TSPAN4 & tetraspanin 4 & 1.50 & 0.008 \\
\hline GMPPA & GDP-mannose pyrophosphorylase A & 1.50 & 0.016 \\
\hline$C H A D$ & chondroadherin & 1.50 & 0.005 \\
\hline$B C K D K$ & branched chain ketoacid dehydrogenase kinase & 1.50 & 0.014 \\
\hline ACTNI & actinin, alpha I & 1.50 & 0.006 \\
\hline
\end{tabular}

Adj $P$ is the $P$-value following adjustment for multiple testing.

Table 3: Genes $\geq-1.5$-fold (down-regulated) differential expression four hours post-exercise compared to pre-exercise levels.

\begin{tabular}{|c|c|c|c|}
\hline Gene Symbol & Gene Name & Fold change & $\operatorname{adj} P$ \\
\hline ACTRIO & actin-related protein 10 homolog (S. cerevisiae) & -1.73 & 0.042 \\
\hline ANXA7 & annexin $A 7$ & -1.73 & 0.039 \\
\hline CBX3 & chromobox homolog 3 (HPI gamma homolog, Drosophila) & $-1.5 \mid$ & 0.010 \\
\hline $\mathrm{Cl} 2$ orf57 & chromosome 12 open reading frame 57 & -1.52 & 0.008 \\
\hline CI 7 orf37 & chromosome 17 open reading frame 37 & -1.59 & 0.011 \\
\hline COPB2 & coatomer protein complex, subunit beta 2 (beta prime) & -1.55 & 0.009 \\
\hline $\mathrm{CFH}$ & complement factor $\mathrm{H}$ & -1.63 & 0.035 \\
\hline CWFI9L2 & CWFI9-like 2, cell cycle control (S. pombe) & -2.87 & 2.67E-03 \\
\hline CWFI9L2 & CWFI9-like 2, cell cycle control (S. pombe) & -2.14 & 0.003 \\
\hline CYCS & cytochrome c, somatic & -1.52 & 0.012 \\
\hline FBXW5 & F-box and WD repeat domain containing 5 & -1.57 & 0.007 \\
\hline GALM & galactose mutarotase (aldose I-epimerase) & -1.62 & 0.023 \\
\hline GLB I & galactosidase, beta I & -1.54 & 0.006 \\
\hline GNL3 & guanine nucleotide binding protein-like 3 (nucleolar) & -1.54 & 0.019 \\
\hline HBSIL & HBSI-like (S. cerevisiae) & -1.70 & 0.042 \\
\hline HBSIL & HBSI-like (S. cerevisiae) & -1.62 & 0.047 \\
\hline KLHL2 & kelch-like 2, Mayven (Drosophila) & -1.66 & 0.040 \\
\hline LRRC8D & leucine rich repeat containing 8 family, member D & -1.67 & 0.039 \\
\hline MEI & malic enzyme I, NADP(+)-dependent, cytosolic & -1.59 & 0.003 \\
\hline MUT & methylmalonyl Coenzyme A mutase & -1.59 & 0.014 \\
\hline MIPEP & mitochondrial intermediate peptidase & -1.69 & 0.012 \\
\hline MRPL39 & mitochondrial ribosomal protein L39 & -1.52 & 0.013 \\
\hline NDUFA $/ 2$ & NADH dehydrogenase (ubiquinone) I alpha subcomplex, 12 & -1.50 & 0.020 \\
\hline NDN & necdin homolog (mouse) & -2.01 & 0.004 \\
\hline NEDD $/$ & neural precursor cell expressed, developmentally down-regulated I & -1.52 & 0.022 \\
\hline PCOLCE2 & procollagen C-endopeptidase enhancer 2 & -2.10 & 0.004 \\
\hline PCOLCE2 & procollagen C-endopeptidase enhancer 2 & -1.62 & 0.010 \\
\hline PCOLCE2 & procollagen C-endopeptidase enhancer 2 & -1.51 & 0.017 \\
\hline QKI & quaking homolog, $\mathrm{KH}$ domain RNA binding (mouse) & -1.54 & 0.020 \\
\hline RTN4 & reticulon 4 & -1.59 & 0.039 \\
\hline RPL22 & ribosomal protein $L 22$ & -1.61 & 0.048 \\
\hline ROBOI & roundabout, axon guidance receptor, homolog I (Drosophila) & -1.83 & 0.007 \\
\hline $\mathrm{SIAH} 2$ & seven in absentia homolog 2 (Drosophila) & -1.55 & 0.023 \\
\hline TXNDCI 7 & thioredoxin domain containing 17 & -2.15 & 0.005 \\
\hline TRAMI & translocation associated membrane protein I & -1.87 & 0.008 \\
\hline UXSI & UDP-glucuronate decarboxylase I & -2.21 & 0.016 \\
\hline $\mathrm{Cl}$ 3orf8 & uncharactherised protein & $-1.5 \mid$ & 0.020 \\
\hline VPS33A & vacuolar protein sorting 33 homolog A (S. cerevisiae) & -1.70 & 0.048 \\
\hline
\end{tabular}

Adj $P$ is the $P$-value following adjustment for multiple testing. 
Hsp70 can also interact with proteins involved in the regulation of cellular redox balance and $\mathrm{Ca}^{2+}$ homeostasis, and thus reduce oxidative stress and $\mathrm{Ca}^{2+}$ overload in response to physiological stress [36]. In addition Hsp70 protects against muscular degeneration and atrophy [37] through inhibition of caspase activation [38] and protein catabolism [37] and Hsp70 protein levels have been shown to correlate with muscular regeneration following injury [39]. Together these facts highlight the key role of Hsp70 in muscle protection following stress and as a modulator of muscular regeneration. The HSPA1A gene displayed a further increase in transcript expression at $\mathrm{T}_{2}$ (+4.8-fold, $P<0.001)$, whereas the expression of FOS, EGR1 and PFKFB3 had returned to resting levels. This suggests that while FOS, EGR1 and PFKFB3 responses may be immediate and transient, the HSPA1A response likely contributes to long term adaptation.

The probe upstream of the PFKFB3 gene shares strong homology to mammalian homologues of the gene thus it is likely that it represents expression of this gene product. The product of the PFKFB3 gene is involved in various aspects of energy sensing and metabolism, but has not previously been shown to be increased due to exercise. However, studies have shown increased expression of PFKFB3 in response to glucose deprivation [40] and hypoxia [41], both stimuli associated with exercise. The PFKFB3 protein is a powerful activator of glycolysis [42]. Surprisingly, in a panel of genes encoding glycolytic enzymes and other anaerobic metabolites, differential mRNA expression was not observed in this experimental cohort despite significant increases in plasma lactate concentrations [43]. Similar observations of a lack of transcriptional activation of glycolytic genes have been made in human exercise studies [44]. PFKFB3 is also involved in glucose-induced insulin secretion in pancreatic $\beta$ cells [45] and a SNP in the 3' untranslated region of the PFKFB3 gene is associated with obesity in humans [46]. The PFKFB3 gene promoter contains hypoxic response elements necessary for transactivation by hypoxia-inducible factor-1 alpha (HIF-1 $\alpha$ ) in response to hypoxia [47]. This is relevant considering the observed increase in HIF$1 \alpha$ protein in this cohort of horses immediately after exercise [43].

There was some overlap among probes differentially expressed at $\mathrm{T}_{2}$ and those tending towards differential expression at $\mathrm{T}_{1}$. Among the 434 probes tending towards differential expression (unadjusted $P<0.05$ ) at $\mathrm{T}_{1} 154$ were also among those at $\mathrm{T}_{2}$, which is more than twice as many expected by chance. Over $96 \%$ of the genes had both the same direction of regulation at both time-points and a greater magnitude of change at $\mathrm{T}_{2}$. Two genes had a greater magnitude of change at $\mathrm{T}_{1}$ and a different directionality was observed for four genes. The genes with the highest observed fold changes at both $\mathrm{T}_{1}$ and $\mathrm{T}_{2}$ included HSPA1A (heat shock $70 \mathrm{kDa}$ protein $1 \mathrm{~A}$ gene, $\mathrm{T}_{1}$ : +2.6fold (mean of two probes), unadjusted $P=1.22 \mathrm{E}-05 ; \mathrm{T}_{2}$ : +4.8 -fold, $P=1.61 \mathrm{E}-05$ ); CRTC2 (CREB regulated transcription coactivator 2 gene, $\mathrm{T}_{1}:+1.3$-fold, adjusted $P=$ $0.001 ; \mathrm{T}_{2}:+1.7$-fold, $P=0.003$ ); and SLC16A3 (solute carrier family 16 , member 13 gene, $\mathrm{T}_{1}:+1.2$-fold, adjusted $P$ $=0.03 ; \mathrm{T}_{2}:+1.6$-fold, $P=0.012$ ).

The CRTC2 protein is a potent activator of PGC-1 $\alpha$ (peroxisome proliferater-activated receptor gamma coactivator 1 alpha), the master regulator of mitochondrial biogenesis [48] and is also involved in the modulation of gluconeogenesis [49]. The SLC16A3 protein is found in greater abundance in fast twitch rather than slow twitch muscle [50] and plays a direct role in lactate efflux out of skeletal muscle. Thoroughbred horses have a strikingly high proportion of fast to slow twitch muscle fibres [51], which was also observed in this cohort of horses [43]. Increased mRNA levels of SLC16A3 were observed in "race fit" compared to moderately conditioned Standardbred horses [52]. SLC16A3 also plays a role in the transport of the performance enhancing drug gamma-hydroxybutyric acid (GHB) [53]. GHB is an endogenous metabolite but can also be administered orally as a performance-enhancing drug; therefore it is reasonable to hypothesize that endogenous GHB metabolism is associated with natural athletic ability. This hypothesis is supported by the observation that the alcohol dehydrogenase iron-containing protein 1 gene (ADHFE1), which is involved in GHB catabolism [54] is located in a genomic region that has been a target for positive selection during four hundred years of Thoroughbred evolution [55].

Overall, these data suggest that, in addition to a rapid and dramatic induction of a small number of stress response genes immediately after exercise, there are also more subtle early changes in gene expression that are difficult to detect but are functionally relevant. It is possible that many of the genes differentially expressed at $\mathrm{T}_{2}$ were also differentially expressed at $T_{1}$, but show more gradual changes in gene expression and were not detectable at that time point.

\section{Overrepresentation of functional ontologies among differentially expressed genes}

The relatively small number of probes ( $n=434$, unadjusted $P<0.05)$ tending towards significant differential expression immediately after exercise suggested that deriving meaningful functional information may be problematic given an expected false discovery rate of approximately 400 probes in this experiment. Therefore the FatiScan gene enrichment test, which incorporates all transcriptional data rather than limiting to only significantly differentially expressed probes was used to analyse 
the transcriptional profile immediately after exercise [56]. Genes were ranked by differential expression and functional blocks that were significantly up-regulated and down-regulated immediately after exercise were identified (Table 4). Overrepresented GO functional groups associated with up-regulated genes included response to stress, RNA metabolism and developmental processes. The overrepresentation of genes involved in the stress response suggests that exercise-induced muscle repair may be a particular requirement for the maintenance of structural integrity in Thoroughbred skeletal muscle following disruption of muscle fibres. This may be understood in the light of very high aerobic and anaerobic capacities in Thoroughbreds, which enable high intensity exercise even in the unconditioned state. The principal GO functional groups associated with down-regulated genes were those involving the ribosome, oxidative phosphorylation and proton-transporting ATP synthase complex. The strong overrepresentation of down-regulated ribosomal genes suggests an inhibition of protein synthesis. Previous studies have reported a reduced rate of protein synthesis $[57,58]$ and observed the disaggregation of polysomes to ribosomes immediately post exercise [59]. The down-regulation of genes associated with oxidative phosphorylation may represent a shift form aerobic towards anaerobic respiration.

The majority of exercise studies investigating the immediate response to exercise have focussed on post-transcriptional or post-translational modifications or have used real time qRT-PCR to investigate a limited number of genes $[21-23,60]$. Because of the lack of literature documenting the immediate transcriptional response to exercise in skeletal muscle it is not clear whether the responses detected in this study are specific to horses, or indeed Thoroughbred horses.

\section{Delayed response to exercise \\ Differentially expressed genes}

A significantly larger number of genes were differentially expressed four hours following exercise. Sixteen genes had very significant $(P<0.01)$ increases in expression with magnitudes $>+1.8$-fold and 104 had had significant $(P<$ $0.05)$ expression differences $>+1.5$-fold. Among the 16 most differentially expressed genes at $\mathrm{T}_{2}$ were HSPA1A (heat shock $70 \mathrm{kDa}$ protein $1 \mathrm{~A}$ gene, +4.8 -fold, $P<0.001$ ); TPM4 (tropomyosin 4 gene; +1.9 -fold, $P=0.008$ ), HSP90AA1 (heat shock protein $90 \mathrm{kDa}$ alpha (cytosolic), class A member 1 gene; +2.2 -fold, $P=0.002$ ) and USP36 (ubiquitin specific peptidase 36 gene; +2.16 -fold, $P=$ $0.001)$. Other notable genes present among those differentially upregulated $(>+1.5$-fold) were HSPA8 (heat shock $70 \mathrm{kDa}$ protein 8 gene; +1.9 -fold, $P=0.003$ ); CRTC2 (CREB-regulated transcription coactivator 2 gene; +1.7 -fold, $P=0.002$ ) and LAMP2 (lysosome-associated membrane glycoprotein 2 precursor gene; +1.6 -fold, $P=$ 0.028 .

Notably genes encoding three heat shock proteins (HSPA1A, HSP90AA1 and HSPA8) were among the most highly differentially regulated transcripts. The Hsp70 (HSPA1A) and Hsp90 (HSP90AA1) proteins have been

Table 4: Significantly up-regulated and down-regulated GO categories immediately post-exercise compared to pre-exercise levels.

\begin{tabular}{|c|c|c|c|}
\hline $\begin{array}{l}\text { GO ID } \\
\text { Up-regulated }\end{array}$ & GO Term & No. Genes & $P$ \\
\hline GO:0006950 & response to stress & 3 & 0.001 \\
\hline GO:0007275 & multicellular organismal development & 6 & 0.001 \\
\hline GO:0048731 & system development & 5 & 0.002 \\
\hline GO:0048856 & anatomical structure development & 5 & 0.003 \\
\hline GO:0009986 & cell surface & 12 & 0.005 \\
\hline GO:0007242 & intracellular signaling cascade & 195 & 0.009 \\
\hline GO:0009897 & external side of plasma membrane & 5 & 0.026 \\
\hline GO:0005794 & Golgi apparatus & 76 & 0.034 \\
\hline GO:0044459 & plasma membrane part & 53 & 0.039 \\
\hline GO:0016070 & RNA metabolic process & 4 & 0.040 \\
\hline \multicolumn{4}{|c|}{ Down-regulated } \\
\hline GO:0003735 & structural constituent of ribosome & 21 & 0.000 \\
\hline GO:0005840 & ribosome & 26 & 0.000 \\
\hline GO:0044445 & cytosolic part & 33 & 0.001 \\
\hline GO:0043228 & non-membrane-bound organelle & 187 & 0.001 \\
\hline GO:0015934 & large ribosomal subunit & 15 & 0.003 \\
\hline GO:0043232 & intracellular non-membrane-bound organelle & 187 & 0.004 \\
\hline GO:0005829 & cytosol & 130 & 0.007 \\
\hline GO:0006119 & oxidative phosphorylation & 28 & 0.039 \\
\hline GO:0045259 & proton-transporting ATP synthase complex & 8 & 0.043 \\
\hline
\end{tabular}

The FatiScan gene enrichment test was used to analyse the data 
shown to be associated with the transport of TOM (Translocases of the outer membrane) complex proteins to the mitochondrial surface $[61,62]$ in response to contractile activity. These proteins in turn are responsible for the import of the hundreds of nuclear encoded proteins that function in the mitochondria $[63,64]$. It clearly follows that the reliance on nuclear encoded proteins for mitochondrial function is subject to the efficiency of protein translocation to the mitochondria While numerous studies have reported Hsp70 and Hsp90 induction in skeletal muscle in response to exercise $[65,66]$, to our knowledge, no study has reported an induction of constitutively expressed HSPA8 protein. On the other hand, HSPA8 has been reported to be induced in rat cardiac muscle following hypoxic exposure [67] and may provide a protective effect following oxidative stress [68]. LAMP-2 is a lysosomal receptor involved in the elimination of misfolded proteins. It has been demonstrated that protesomal inhibition results in an accumulation of Hsp70, LAMP-2 and ubiquitin aggregates [69]. Similarly, the TPM4 protein plays a major role in $\mathrm{Ca}^{2+-}$-regulated skeletal muscle contraction and is upregulated in muscle undergoing regeneration and focal repair [70]. Presumably the up-regulation of the heat shock genes, TPM4, LAMP2 and USP36 reflects activity in the reparation or degradation of damaged and misfolded proteins [69].

Fourteen probes representing 12 genes had very significant $(P<0.01)$ decreases in expression at $\mathrm{T}_{2}$ with magnitudes greater than -1.8-fold. One hundred and twenty-six genes had significant $(P<0.05)$ expression differences greater than -1.5 -fold. The most differentially expressed genes were CWF19L2 (CWF19-like protein gene;represented by two probes, mean -2.5-fold, $P=0.003$ ); UXS1 (UDP-glucuronic acid decarboxylase 1 gene; -2.2-fold, $P=$ 0.016 ); TXNL5 (thioredoxin domain-containing protein 17 gene; -2.2 -fold, $P=0.005$ ); PCOLCE2, (procollagen Cendopeptidase enhancer 2 precursor gene; represented by two probes, mean -1.9-fold, $P=0.004, P=0.01$; $N D N$ (necdin gene; -2.0-fold, $P=0.004$ ); TRAM1 (translocation-associated membrane protein 1 gene; -1.9-fold, $P=$ 0.008 ); and ROBO1 (roundabout homolog 1 precursor gene; -1.8 -fold, $P=0.007)$. Six probes also had decreased expression at $\mathrm{T}_{1}$ (unadjusted $P<0.05$ ) representing GLB1 ( $\mathrm{T}_{1}:$-1.2-fold; $\mathrm{T}_{2}:-1.5$-fold), SETD7 $\left(\mathrm{T}_{1}:-1.1\right.$-fold; $\mathrm{T}_{2}:-1.5$ fold) and four unannotated probes.

\section{Overrepresentation of functional ontologies among differentially expressed genes}

At $T_{2}$ there was an observed overrepresentation of genes that localised to the actin cytoskeleton, actin filament bundle and cortical actin cytoskeleton (Table 5). The overrepresentation of genes associated with the actin cytoskeleton may be indicative of responses to contraction and mechanical stimuli and may be associated with muscle remodelling via sarcomerogenesis. This is consistent with an observed overrepresentation of genes in the focal adhesion pathway. Actin remodelling has also been shown to be responsible for an increase in GLUT4 translocation in skeletal muscle [71]. An overrepresentation of actinrelated gene ontologies following exhaustive exercise has not previously been reported. On the other hand, the observed overrepresentations of genes with intramolecular oxidoreductase activity, unfolded protein binding and heat shock protein binding molecular functions are consistent with human exercise studies that predict replenishment of intramuscular energy stores and a stress response during recovery from intense exercise because of ROS production, inflammation and intramuscular microtears $[8,19]$.

Because of the larger number of genes with assigned biological processes (497) the returned GO classes had more general higher level functions (e.g. protein folding, regulation of catalytic activity and regulation of the cell cycle) providing little insight into the underlying adaptive mechanisms. Therefore, we searched for overrepresented KEGG pathways among the significantly differentially regulated genes at $\mathrm{T}_{2}$. These included the well established exercise response pathways, insulin signalling [68], Type II diabetes mellitus [72], mTOR signalling [73] and MAPK signaling [74-76] as well as focal adhesion and p53 signaling pathway. A list of genes differentially expressed in these pathways is provided in additional file 4 . The overrepresented KEGG pathways are associated with different but overlapping aspects of exercise stimuli and support the hypothesis that the genes governing these cellular pathways have been targets for selection for exercise adaptation in Thoroughbreds [55].

The less well described focal adhesion and p53 signaling pathways are of particular note for their roles in muscle hypertrophy and metabolic improvements. Muscle stretch gives rise to the generation of focal adhesion complexes through the induction of actin polymerisation at focal adhesions and an increase in focal adhesion complex associated proteins has been found in hypertrophic muscle $[77,78]$. For instance, the mechanosensitive extra cellular matrix protein tenascin-C has been identified as a critical regulator of gene expression relating to repair and growth in muscle following damaging exercise [79]. Furthermore, focal adhesion kinase (FAK) has been shown to be an upstream regulator of the control of muscle mass via p70S6K [80] which may signal mTOR [81] independent of Akt. The central role of FAK in muscle growth and differentiation has been recently been demonstrated. Overexpression of FAK led to a shift towards slow twitch muscle generation and an up-regulation of genes involved in mitochondrial metabolism and contraction [82]. Therefore, an overrepresentation of focal adhesion molecules 
Table 5: GO categories and KEGG pathways overrepresented among differentially expressed genes $(P \leq 0.05)$ four hours post-exercise compared to pre-exercise levels.

\begin{tabular}{|c|c|c|c|c|}
\hline $\begin{array}{l}\text { GO ID } \\
\text { Molecular Function }\end{array}$ & GO Term & No. Genes & $\boldsymbol{P}$ & Fold Enrichment \\
\hline GO:00055I5 & protein binding & 352 & 0.004 & 1.09 \\
\hline GO:0016853 & isomerase activity & 19 & 0.007 & 1.85 \\
\hline GO:0005200 & structural constituent of cytoskeleton & 7 & 0.026 & 2.72 \\
\hline GO:0003700 & transcription factor activity & 39 & 0.031 & 1.36 \\
\hline GO:0016860 & intramolecular oxidoreductase activity & 8 & 0.037 & 2.33 \\
\hline GO:0031072 & heat shock protein binding & 9 & 0.078 & 1.91 \\
\hline GO:005I082 & unfolded protein binding & 16 & 0.096 & 1.49 \\
\hline \multicolumn{5}{|c|}{ Cellular Compartment } \\
\hline GO:0044428 & nuclear part & 83 & 0.009 & 1.27 \\
\hline GO:0044446 & intracellular organelle part & 194 & 0.015 & 1.13 \\
\hline GO:0044422 & organelle part & 195 & 0.016 & 1.13 \\
\hline GO:0031974 & membrane-enclosed lumen & 75 & 0.018 & 1.26 \\
\hline GO:0043233 & organelle lumen & 75 & 0.018 & 1.26 \\
\hline GO:0005667 & transcription factor complex & 19 & 0.024 & 1.67 \\
\hline GO:00I5629 & actin cytoskeleton & 15 & 0.029 & 1.78 \\
\hline GO:004445I & nucleoplasm part & 37 & 0.032 & 1.37 \\
\hline GO:0005886 & plasma membrane & 79 & 0.042 & 1.20 \\
\hline GO:0016020 & membrane & 222 & 0.049 & 1.09 \\
\hline GO:0005654 & nucleoplasm & 40 & 0.061 & 1.29 \\
\hline GO:0031981 & nuclear lumen & 51 & 0.064 & 1.24 \\
\hline GO:0001725 & stress fiber & 4 & 0.066 & 3.79 \\
\hline GO:0032432 & actin filament bundle & 4 & 0.066 & 3.79 \\
\hline GO:0030864 & cortical actin cytoskeleton & 4 & 0.066 & 3.79 \\
\hline GO:0030863 & cortical cytoskeleton & 5 & 0.066 & 2.96 \\
\hline GO:0030054 & cell junction & 15 & 0.074 & 1.58 \\
\hline GO:0044433 & cytoplasmic vesicle part & 10 & 0.077 & 1.82 \\
\hline GO:0030659 & cytoplasmic vesicle membrane & 10 & 0.077 & 1.82 \\
\hline GO:0044448 & cell cortex part & 6 & 0.087 & 2.37 \\
\hline GO:0031410 & cytoplasmic vesicle & 28 & 0.090 & 1.33 \\
\hline GO:00I2506 & vesicle membrane & 10 & 0.095 & 1.75 \\
\hline GO:0016023 & cytoplasmic membrane-bound vesicle & 24 & 0.098 & 1.35 \\
\hline GO:0005770 & late endosome & 7 & 0.100 & 2.07 \\
\hline \multicolumn{5}{|l|}{ Biological Process } \\
\hline GO:005I640 & organelle localization & 5 & 0.021 & 3.92 \\
\hline GO:0006457 & protein folding & 29 & 0.029 & 1.45 \\
\hline GO:005I650 & establishment of vesicle localization & 4 & 0.032 & 4.70 \\
\hline GO:005I648 & vesicle localization & 4 & 0.032 & 4.70 \\
\hline GO:0006903 & vesicle targeting & 4 & 0.032 & 4.70 \\
\hline GO:0050790 & regulation of catalytic activity & 26 & 0.044 & 1.44 \\
\hline GO:005I726 & regulation of cell cycle & 34 & 0.045 & 1.36 \\
\hline GO:0000074 & regulation of progression through cell cycle & 34 & 0.045 & 1.36 \\
\hline GO:0048523 & negative regulation of cellular process & 64 & 0.050 & 1.22 \\
\hline GO:0016568 & chromatin modification & 19 & 0.058 & 1.51 \\
\hline GO:005I656 & establishment of organelle localization & 4 & 0.067 & 3.76 \\
\hline GO:0065009 & regulation of a molecular function & 29 & 0.076 & 1.34 \\
\hline GO:0048519 & negative regulation of biological process & 65 & 0.080 & 1.19 \\
\hline GO:0007049 & cell cycle & 49 & 0.080 & 1.23 \\
\hline GO:003।324 & negative regulation of cellular metabolic process & 25 & 0.082 & 1.37 \\
\hline \multicolumn{5}{|l|}{ KEGG ID } \\
\hline hsa040I0 & MAPK signaling pathway & 13 & 0.060 & 1.69 \\
\hline hsa045I0 & Focal adhesion & 17 & 0.099 & 1.45 \\
\hline hsa04II 5 & p53 signaling pathway & 5 & 0.163 & 2.24 \\
\hline hsa00590 & Arachidonic acid metabolism & 3 & 0.182 & 3.70 \\
\hline hsa04910 & Insulin signaling pathway & 9 & 0.183 & 1.59 \\
\hline hsa052II & Renal cell carcinoma & 7 & 0.198 & 1.73 \\
\hline hsa04670 & Leukocyte transendothelial migration & 7 & 0.233 & 1.64 \\
\hline hsa04I50 & mTOR signaling pathway & 4 & 0.265 & 2.19 \\
\hline hsa00720 & Reductive carboxylate cycle (CO2 fixation) & 3 & 0.265 & 2.96 \\
\hline hsa04930 & Type II diabetes mellitus & 3 & 0.265 & 2.96 \\
\hline
\end{tabular}

The FatiScan gene enrichment test was used to analyse the data 
indicates the importance of mechanical force altering skeletal muscle gene regulation towards muscle growth and remodelling [83]. Moreover, we have previously determined that focal adhesion molecules may represent targets for recent artificial selection in the Thoroughbred and therefore may be critical to the development of the muscle strength phenotype for which Thoroughbreds are renowned [55]. The $\mathrm{p} 53$ protein is best known for its role in apoptosis, however, recent studies have suggested that the p53 signaling pathway may play a role in regulation of aerobic metabolism with significant reductions in COX4 activity in $\mathrm{KO}$ mice $[84,85]$. Importantly, p53 may regulate the expression of PGC-1 $\alpha[86]$.

Other KEGG pathways that were overrepresented were: arachidonic acid metabolism, involved in the modulation of function of voltage gated ion channels, primarily in neurons and muscle cells [87]; leukocyte transendothelial migration, associated with the inflammatory response and largely coordinated by chemokines $[88,89]$; reductive carboxylate cycle ( $\mathrm{CO}_{2}$ fixation), a metabolic pathway; and the renal cell carcinoma signalling pathway, which involves increased cell proliferation, energy demand and $\mathrm{O}_{2}$ usage and is stimulated by hypoxia and HIF- $1 \alpha$ $[90,91]$.

\section{Validation of a panel of genes by real time qRT-PCR}

Nine genes that were found to be differentially expressed in the microarray experiment were selected for validation by real time qRT-PCR. These genes were chosen based on their involvement in muscle contraction or the response to hypoxia. Two probes (Genbank IDs: CX594334 and CX598227) that showed differential expression, but were not found within an annotated gene were also included for validation. CX594334 lies $2 \mathrm{~kb}$ upstream of PFKFB3 and was upregulated immediately post-exercise. CX598227 lies $1 \mathrm{~kb}$ downstream of calmodulin 1 (Calm1) and was upregulated four hours post exercise. The average gene expression of seven of the nine probes studied reached significance $(P<0.05)$ and six [(basic helix-loop-helix family, member e40 (BHLHE40), calmodulin 3(CALM3), HSPA1A, FOS, CX594334 and CALM1] were concordant with the microarray data (Table 6 , Figure 1). A point of major concern in microarray studies is the presence of false positives within a gene list. Although the use of qRT-PCR is essential to validate the overall dataset it is not feasible to interpret the experimental findings by evaluating each gene individually. As genes function in co-operation within complex networks we report principally the expression patterns of functionally related groups of genes.

There were however, some interesting findings among the validated genes. For instance, the expression of FOS showed a high inter-sample variance in gene expression change estimates $(+18.2$-fold to +506.0 -fold increase) . The mean expression of the FOS gene mRNA transcript increased +198 -fold. The biological significance of the high gene expression variance for this gene is not clear at present but warrants further investigation.

Transcripts for the HSPA1A gene and the probe CX594334 (which may represent the PFKFB3 gene) were significantly increased at $\mathrm{T}_{1}$ (2.3-fold and 2.7-fold fold respectively). While both genes have quite different physiological roles $[42,92]$ both contain hypoxic response elements (HRE) and have been shown to be transcriptionally activated by the HIF- $1 \alpha$ protein under hypoxic conditions [93].

During the recovery period, four hours post exercise, HSPA1A mRNA levels remained elevated (+5.9-fold) while CX594334 transcript levels returned to baseline (Figure 1). The BHLHE40 gene, which increased in expression +2.3 -fold is a transcription factor involved in the hypoxic response, contains a HRE and is inducible in hypoxic conditions through interaction with HIF- $1 \alpha$ $[94,95]$. CALM3 and CX598227 which lies $\sim 1$ kb downstream of CALM1 showed directionally different changes in gene expression. CALM3 was downregulated -0.82-fold while CX598227 was upregulated +2.4 -fold. This is of particular interest as little is known regarding the differential regulation of the individual genes within the Calmodulin gene family. Calmodulin is a calcium binding protein which acts as a calcium sensor [96] and plays an important role in mediating many cellular processes including muscle contraction $[97,98]$.

\section{Conclusion}

The Thoroughbred horse provides a singular model system to understand exercise adaptations. For the first time following exhaustive exercise we have identified a large number of genes with functions in mechanosensation, muscle hypertrophy, repair and remodelling. The induction of the large numbers of genes with such functions may be explained by the extraordinary innate aerobic and anaerobic capacity of Thoroughbreds enabling high intensity exercise even in an unconditioned state leading to proportionally greater stresses on peripheral systems than in other species. Importantly it is unlikely this knowledge could be readily gained from human studies as the sustained "all out" effort required to elicit such molecular responses is difficult to attain from untrained/sedentary human subjects, but is naturally achieved by Thoroughbreds.

The standard exercise test employed in equine exercise physiology studies requires both endurance and strength, a combination that is not easily reconstructed in other exercise models. The result is that immediately after exercise ribosomal genes are down-regulated indicating 

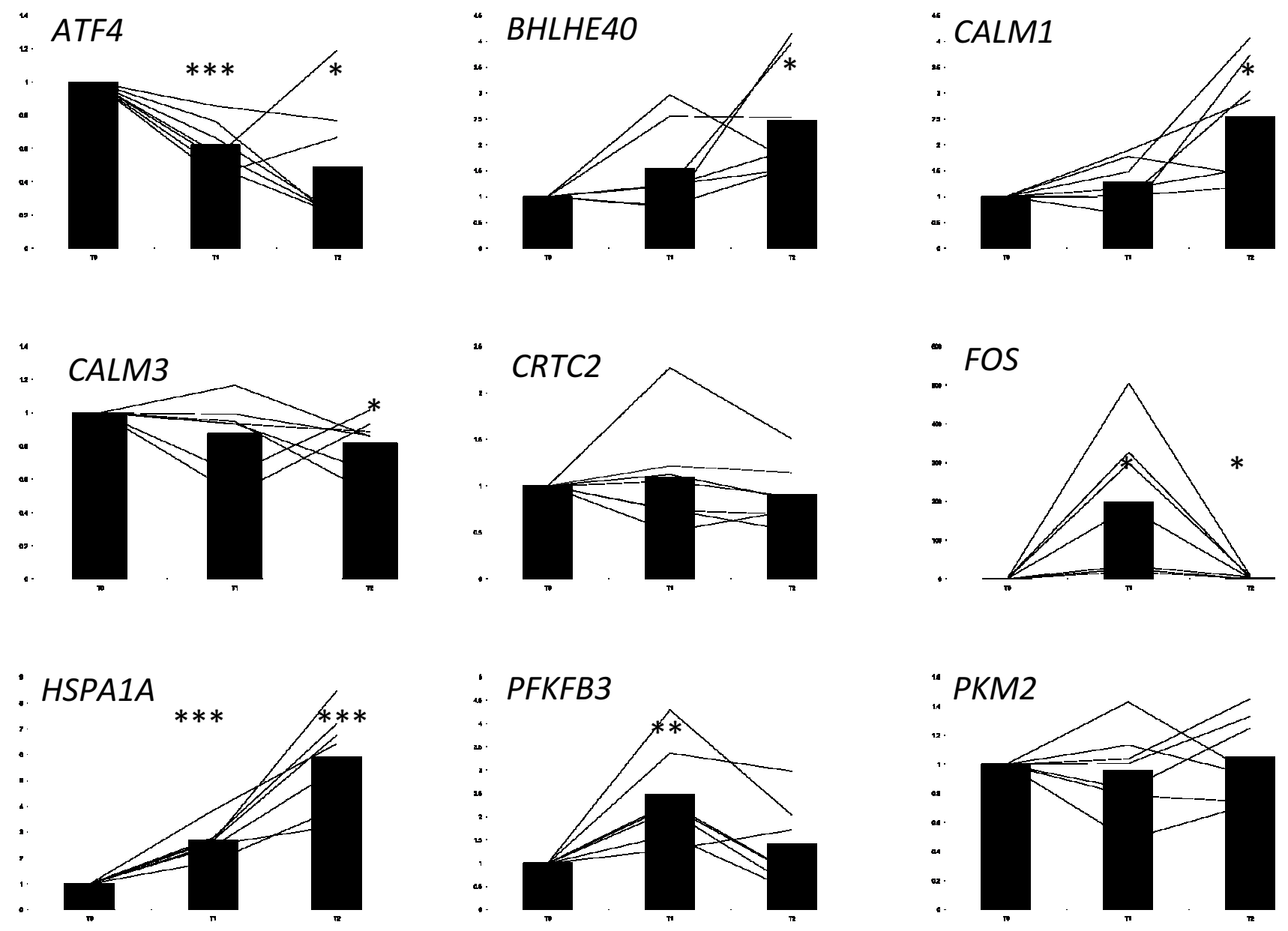

Figure I

Real time qRT-PCR results for genes used to validate microarray data. The standard 2- $\Delta \Delta C T$ method was used to determine mean fold changes in gene expression [I I6]. All Ct values were normalised using the NSUN6 gene. The Student's ttest was used to identify significant differences in mRNA abundance between time-points. Each point on the graph represents the relative fold change in gene expression compared to pre-exercise levels. * signifies a $\mathrm{P}$-value of $<0.05 * *$, signifies a $\mathrm{P}$-value of $<0.0$ I, *** signifies a P-value of $<0.00$ I

decreased protein synthesis, a signature of endurance exercise. However, established responses associated with resistance exercise such as muscle repair and hypertrophy are observed four hours after exercise. Although the inhibition of protein synthesis and muscle hypertrophy are established responses to endurance and resistance exercise respectively here we detect both responses at a global transcriptional level from a single exercise bout combining both endurance and resistance stimuli.

This study has provided a snapshot of the transcriptional response to exercise in skeletal muscle from a highly adapted system. Genes that were differentially expressed immediately after exercise are likely to be directly involved in metabolism and the stress response. Four hours following exercise a more general transcriptional response associated with recovery and adaptation was observed, in particular highlighting the roles of genes in metabolism and muscle hypertrophy. Further studies are needed to clearly distinguish between the mechanisms associated with the recovery from exercise and return to homeostasis and those that are involved in the long term adaptive response to recurring bouts of exercise conditioning.

\section{Methods}

All animal procedures were approved by the University College Dublin, Animal Research Ethics Committee. In addition, a licence was granted from the Department of 
Table 6: Real time qRT-PCR results for genes used to validate microarray data

\begin{tabular}{|c|c|c|c|c|c|}
\hline \multirow[t]{2}{*}{ Gene symbol } & \multirow[t]{2}{*}{ GenBank ID } & \multicolumn{2}{|c|}{ Microarray } & \multicolumn{2}{|c|}{ qRT-PCR } \\
\hline & & FC $T_{1}$ & $P$ & $\mathbf{F C ~} \mathbf{T}_{1}$ & $P$ \\
\hline HSPAIA & CX60257I & 3.11 & 0.001 & 2.68 & 2.87E-04 \\
\hline PFKFB3 & CX594334 & 1.84 & 0.023 & 2.30 & 0.010 \\
\hline \multirow[t]{2}{*}{ FOS } & CX604427 & 2.13 & 0.997 & 198.90 & 0.031 \\
\hline & & $\mathbf{F C ~} \mathbf{T}_{2}$ & $P$ & $\mathbf{F C ~ T}_{2}$ & $P$ \\
\hline ATF4 & CX603997 & 1.50 & 0.005 & -2.04 & 0.014 \\
\hline BHLHE40 & CX599005 & 1.44 & 0.008 & 2.25 & 0.014 \\
\hline CALM3 & CX600504 & -1.40 & 0.045 & -1.22 & 0.031 \\
\hline CRTC2 & CX604423 & 1.58 & 0.004 & -1.12 & 0.483 \\
\hline Calm I & CX598227 & 1.49 & 0.004 & 2.36 & 0.010 \\
\hline HSPAIA & CX60257I & 4.84 & I.6E-05 & 5.91 & 4.08E-04 \\
\hline PKM2 & CX594899 & 1.63 & 0.028 & 1.05 & 0.648 \\
\hline
\end{tabular}

FC $T_{\text {I }}$ represents the fold change in gene expression immediately post-exercise.

$F C T_{2}$ represents the fold change in gene expression four hours exercise post-exercise.

Health and Children (Ireland) and owners' consent was obtained for all horses.

\section{Subjects}

Eight four-year old unconditioned Thoroughbred horses (castrated males), raised at the same farm for the previous 12 months and destined for National Hunt racing with the same trainer comprised the study cohort. The horses had a mean height of $165.25 \mathrm{~cm}(( \pm 1.44)$ and a mean pre-exercise weight of $565.75 \mathrm{~kg}( \pm 13.71)$. All horses participated in a standardized incremental-step exercise test [25-27] on a high-speed equine treadmill (Sato, Sato AB, Knivsta, Sweden). Before the exercise test, all horses were judged to be clinically healthy based on a veterinary examination that included a lameness assessment, resting upper airway endoscopy and basic bloodwork (complete blood count and serum biochemistry). Prior to entering the study, all of the horses had been raised together and had been kept in a grass field and fed $1.8 \mathrm{~kg}$ of $14 \%$ Race horses cubes (Gain horse feeds, Clonroche, Co. Wexford, Ireland) three times a day. During the study week the horses were housed in a stable and provided ab libitum access to water and fed grass hay and $2 \mathrm{~kg}$ of $10 \%$ Cool-nCooked Horse and Pony Mix (Connolly's Red Mills, Bagnelstown, Co. Carlow, Ireland) twice daily. Horses were fed approximately 3 hours and 55 minutes $(235 \pm 0.11$ minutes) prior to the exercise test. All exercise tests were performed between 1000 - $1130 \mathrm{am}$.

\section{Standardised exercise test}

The treadmill was housed in an insulated room with temperature and humidity monitors. Prior to the exercise test, all horses were acclimatized to stand quietly and to comfortably transition gaits on the treadmill. The treadmill was set to a $6^{\circ}$ incline for all of the exercise tests. The warm-up period consisted of 2 minutes at $2 \mathrm{~m} / \mathrm{s}$, followed by 2 minutes at $4 \mathrm{~m} / \mathrm{s}$ and then 2 minutes at $6 \mathrm{~m} / \mathrm{s}$. This was then followed by an increase in treadmill velocity to
$9 \mathrm{~m} / \mathrm{s}$ for 60 seconds, and then a $1 \mathrm{~m} / \mathrm{s}$ increase in treadmill velocity every 60 seconds until the animal was no longer able to maintain its position on the treadmill at that speed or until the heart rate reached a plateau $\left(\mathrm{HR}_{\max }\right)$. Following completion of the test, the horses were quickly brought back to a walk, taken off the treadmill and washed down with cold water.

\section{Instrumentation}

Any instrumentation was performed 30 minutes to 1 hour prior to the exercise test. Heart rate (HR) was measured continuously before, during and after exercise by telemetry (Polar Equine S810i heart rate monitor system, Polar Electro Ltd, Warwick United Kingdom). Venous blood samples were collected immediately after exercise, $5 \mathrm{~min}$ utes after exercise and 4 hours post-exercise. Blood samples were collected and placed into fluoride oxalate tubes for the determination of plasma lactate concentrations. All tubes were stored on ice with the plasma separated within 1 hour of collection and analyzed within $30 \mathrm{~min}$ utes using the YSI 2300 STAT Plus ${ }^{\text {TM }}$ lactate analyzer (YSI UK Ltd, Hampshire, UK).

\section{Muscle biopsy sampling}

Percutaneous needle muscle biopsies [99] were obtained from the dorsal compartment of the gluteus medius muscle according to Dingboom and colleagues [100] using a 6 $\mathrm{mm}$ diameter, modified Bergstrom biopsy needle (Jørgen KRUUSE, Veterinary Supplies). Biopsies were taken approximately $15 \mathrm{~cm}$ caudodorsal (one-third of the distance) to the tuber coxae on an imaginary line drawn from the tuber coxae to the head of the tail. The biopsies were obtained at a depth of $80 \mathrm{~mm}$. Each biopsy site was shaved, scrubbed with an antiseptic and desensitized by a local anaesthetic. The biopsy samples were washed with sterile PBS (BD Biosciences, San Jose, CA) and preserved in RNAlater (Ambion, UK) for 24 hours at $4^{\circ} \mathrm{C}$ and then stored at $-20^{\circ} \mathrm{C}$. 
Muscle biopsy samples were collected at three time points: at rest pre-exercise $\left(\mathrm{T}_{0}\right)$, immediately post-exercise $\left(T_{1}\right)$ and four hours post-exercise $\left(T_{2}\right)$. Pre-exercise biopsies were collected within 93 minutes (range 68 - 93 mins) before the commencement of exercise and between 155 and 170 minutes post feeding. The immediately post-exercise $\left(T_{1}\right)$ biopsies were collected within seven minutes 30 seconds (range 5 mins $45 \mathrm{sec}$ - 7 mins $30 \mathrm{sec}$ ) following cessation of exercise and four hour post-exercise $\left(T_{2}\right)$ biopsies were collected within 262 minutes (range 242 262 mins) following cessation of exercise.

\section{RNA isolation and purification}

Approximately $100 \mathrm{mg}$ of each muscle biopsy sample was removed from RNAlater and homogenized in $3 \mathrm{ml}$ TRIzol using a Kinematica Polytron Homogeniser PT 1200 C Drive unit, $230 \mathrm{~V}$ (AGB, Dublin, Ireland) and the aqueous and organic phases were separated using $200 \mu \mathrm{l}$ of chloroform. Total RNA was precipitated using isopropyl alcohol ( 0.6 times the volume of the aqueous phase). The remaining pellet was washed once in $75 \%$ ethanol, and redissolved in $35 \mu$ l of nuclease-free water (Promega UK Ltd, Southampton, UK). Each sample was purified using the RNeasy ${ }^{\circledR}$ Mini kit (Qiagen Ltd, Crawley, UK) and DNase treated with RNase free DNase (Qiagen Ltd, Crawley, UK). To elute the total RNA, $35 \mu$ lof nuclease-free water were applied to the silica-gel membrane of the column to elute the total RNA, which was stored at $-80^{\circ} \mathrm{C}$. RNA was quantified using a NanoDrop ${ }^{\circledast}$ ND1000 spectrophotometer V 3.5.2 (NanoDrop Technologies, Wilmington, DE) and RNA quality was subsequently assessed using the $18 \mathrm{~S} / 28 \mathrm{~S}$ ratio and RNA integrity number (RIN) on an Agilent Bioanalyser with the RNA 6000 Nano LabChip kit (Agilent Technologies Ireland Ltd, Dublin, Ireland) according to manufacturer's instructions. The RNA isolated from these samples had an average RNA integrity number (RIN) of $8.43 \pm 0.08$ (range $8.0-9.0$ ).

\section{Microarray description and annotation}

Microarray slides were printed with clones selected from a cDNA library generated using mRNA purified from the articular cartilage of a 15-month old male Thoroughbred horse [101]. Probe sets on the microarray slides were prepared and printed as previously described $[102,103]$.

The cDNA sequences for all annotated genes on the Equus caballus Version 2.0. (EquCab2.0) genome sequence http:/ /www.broad.mit.edu/mammals/horse/ were downloaded from Ensembl http://www.ensembl.org, release 50. The expressed sequence tag (EST) sequences of all the probes on the array were masked to remove repeats using RepeatMasker [104] and blast searched against the cDNAs. BLAST hits were filtered to retain only hits with e values $\leq$ $10^{-10}, \geq 50$ bp long, above $95 \%$ match-target identity, and where the best hit $e$ value was $\geq 10^{10}$ better than the next best. The EST sequences were cross-matched to horse Entrez gene IDs and to human Ensembl and Entrez gene IDs via accessions. EST matches to multiple horse or human genes were excluded. Because fewer than $50 \%$ of ESTs matched an Ensembl gene predicted gene annotations were assigned to unannotated probes of interest based on the gene located closest to the probe and homology to mammalian genes. Following a BLAST of RefSeq and protein databases search hits with an e value of $<1^{-10}$ and hits on non-mammalian species were eliminated. If the predicted gene annotations based on location and homology did not match, the probe was not assigned a predicted annotation.

\section{Microarray hybridisation and experimental design}

Total RNA was amplified using a MessageAmpTM amplified RNA (aRNA) linear amplification kit (Ambion). $2 \mu \mathrm{g}$ of aRNA was reverse transcribed and directly labelled with Fluor647 or Fluor555 using the SuperScript ${ }^{\mathrm{TM}}$ Plus Direct cDNA Labeling System (Bio-sciences, Dublin Ireland) according to the manufacturer's instructions. Labelled samples were combined and co-hybridised on equine cDNA microarrays using SlideHyb Glass Array Hybridisation Buffer \#3 (Applied Biosystems, Cambridgeshire, UK). Microarray hybridisations were performed on an automated HS400 hybridisation station (Tecan Group Ltd. Seestrasse 103 CH-8708 Männedorf, Switzerland) with the following protocol - wash: $75^{\circ} \mathrm{C}$, runs 1 , wash $10 \mathrm{~s}$, soak $20 \mathrm{~s}$; probe injection: $85^{\circ} \mathrm{C}$; denaturation: $95^{\circ} \mathrm{C}, 2$ min; hybridisation: $42^{\circ} \mathrm{C}$, agitation frequency medium, 4 $\mathrm{h}$; hybridisation: $35^{\circ} \mathrm{C}$, agitation frequency medium, $4 \mathrm{~h}$; hybridisation: $30^{\circ} \mathrm{C}$, agitation frequency medium, $4 \mathrm{~h}$; wash: $37^{\circ} \mathrm{C}$, runs 2 , wash $10 \mathrm{~s}$, soak $20 \mathrm{~s}$; wash: $25^{\circ} \mathrm{C}$, runs 2 , wash $15 \mathrm{~s}$, soak $30 \mathrm{~s}$; wash: $25^{\circ} \mathrm{C}$, runs 2 , wash 20 s, soak $40 \mathrm{~s}$; slide drying: $25^{\circ} \mathrm{C} 2 \mathrm{~min}$.

The experimental design was a direct comparison for each animal between pre- and both post-exercise time points. Each slide was hybridised with samples from $T_{0} V s T_{1}$ and from $\mathrm{T}_{0} V s \mathrm{~T}_{2}$ for each animal. Technical replicates in the form of a dye swap were performed for each investigation.

\section{Microarray scanning and data acquisition}

Hybridised and dried slides were scanned using a GenePix 4000B scanner (Molecular Devices, Berkshire, UK) and image acquisition, first-pass data analysis and filtering were carried out using the GenePix 6.0 microarray image analysis package (Molecular Devices, Berkshire, UK). As a first step of feature extraction spots that were flagged as 'poor' by the GenePix software (due to signal foreground or background contamination, shape irregularity or poor spot quality) were assigned a weight of zero and were excluded from differential expression analyses. Images of the slides were visually examined and any obvious irregularities were also flagged, assigned a weight of zero and 
excluded from differential expression analyses. All spots with a mean signal of less than background plus two standard deviations were flagged and were also excluded from differential expression analyses.

\section{Microarray data analyses}

All statistical analyses on the gene expression data were performed using the R language, version 2.5.1 [105] and the packages statmod and LIMMA from the Bioconductor project [106]. Robust multichip average (RMA) [107] and print tip lowess normalization $[108,109]$ were performed on the data before differential expression analyses were performed using the ImFit function in LIMMA. Fluor647:Fluor555 $\log _{2}$ ratios were calculated for each spot on the microarray and duplicate spots were averaged. The function duplicateCorrelation [110] was used to estimate the correlation between technical replicates (dye swaps) by fitting a mixed linear model by REML individually for each probe. The function also returned a consensus correlation, which is a robust average of the individual correlations. This was used to fit a linear model to the expression data for each probe taking into account the inter-technical replicate correlation between each microarray hybridisation.

Differentially expressed targets were determined using a Bayes moderated t-test [111]. Multiple testing was addressed by controlling the false discovery rate (FDR) using the correction of Benjamini and Hochberg [112]. A probe was flagged as differentially expressed if the corrected $P$ value was $<0.05$.

\section{Functional clustering according to gene ontology annotations}

A list of Entrez IDs of human homologs of probes on the microarray was obtained in a similar manner as for microarray annotation. Using the Entrez IDs of human homologues of equine genes it was possible to use the Database for Annotation, Visualization and Integrated Discovery (DAVID) $[28,29]$ for functional clustering and overrepresentation analyses. DAVID was used to investigate the representation of broad gene ontology (GO) categories (Level 1) on the equine cDNA microarray relative to the whole genome.

The DAVID system was also used to cluster differentially expressed genes according to their function. For $\mathrm{T}_{0} v s \mathrm{~T}_{2}$ experiments, a probe was called differentially expressed if its corrected $P$ value was $<0.05$ [112]. The enrichment of categories was assessed and compared with the proportion observed in the total population of genes on the microarray, using the Expression Analysis Systematic Explorer (EASE) tool within DAVID [113]. A different approach was used when functionally clustering differentially expressed genes from the $T_{0} v s T_{1}$ experiments.
Although we expected there would only be small number of genes differentially expressed at $\mathrm{T}_{1}$, there remains the possibility that some more modest but still genuine changes in gene expression may not be detected. Therefore the FatiScan $[56,114]$ gene enrichment test was used to analyse the transcriptional profile immediately after exercise. FatiScan is part of the Babelomics Suite Genes and tests for the asymmetrical distribution of biological labels in an ordered list of genes. Genes were ranked by differential expression and FatiScan was used to detect functional blocks (GO and KEGG pathways) that were significantly up-regulated and down-regulated immediately after exercise.

\section{Quantitative real time RT-PCR}

Selected cDNA samples from seven of the eight animals were quantified by real time qRT-PCR. One of the animals was omitted due to a shortage of RNA in the pre-exercise sample. $1 \mu \mathrm{g}$ of total RNA from each sample was reverse transcribed into cDNA with oligo-dT primers using a SuperScript ${ }^{\mathrm{TM}}$ III first strand synthesis SuperMix kit according to the manufacturer's instructions (Invitrogen Ltd, Paisley, UK). The converted cDNA was diluted to $2.5 \mathrm{ng} /$ $\mu \mathrm{l}$ working stocks and stored at $-20^{\circ} \mathrm{C}$ for subsequent analyses. Oligonucleotide primers for real time qRT-PCR were designed using Primer3 version 3.0 http:// www.primer3.sourceforge.net and commercially synthesized (MWG Biotech, Germany), details of these primers are available in additional file 5. Each reaction was carried out in a total volume of $20 \mu \mathrm{l}$ with $2 \mu \mathrm{l}$ of cDNA $(2.5 \mathrm{ng} /$ $\mu \mathrm{l}), 10 \mu \mathrm{l}$ SYBR $^{\circledast}$ Green PCR Master Mix (Applied Biosystems, Cambridgeshire, UK) and $8 \mu$ primer $/ \mathrm{H}_{2} \mathrm{O}$. Optimal primer concentrations were determined by titrating 50, 300 and $900 \mathrm{nM}$ final concentrations and disassociation curves were examined for the presence of a single product. qRT-PCR was performed using a 7500 Fast RealTime PCR machine (Applied Biosystems, Cambridgeshire, UK).

A panel of four putative reference or 'housekeeping' genes were selected for a reference gene study. This panel comprised two frequently used reference genes (HPRT1, hypoxanthine phosphoribosyltransferase 1 gene; and GAPDH, glyceraldehyde-3-phosphate dehydrogenase gene) and two genes (NSUN6, NOL1/NOP2/Sun domain family, member 6 gene; and PIGO, phosphatidylinositol glycan anchor biosynthesis, class $\mathrm{O}$ gene) that were selected based on minimal variation across the time points observed in the microarray results. The panel of genes was evaluated using geNorm version 3.4 for Microsoft Excel [115]. Briefly, the gene expression stability measure ' $M$ ' for each control gene was calculated as the pairwise variation for that gene with all other tested reference genes across the exercise time-course $\left(T_{0}, T_{1}, T_{2}\right)$. The candidate reference genes were ranked in order of decreas- 
ing ' $M$ ' values or increasing mRNA expression stability [85]. Based on the geNorm analyses, the NSUNG gene was the optimal reference gene and pre-exercise $\left(T_{0}\right)$ values were used to normalise the data. The $2^{-\Delta \Delta \mathrm{CT}}$ method (where CT is cycle threshold) was used to determine mean fold changes in gene expression [116]. The Student's t-test was used to identify significant differences in mRNA abundance between time-points.

\section{Authors' contributions}

$\mathrm{EH}, \mathrm{DMacH}$ and LK conceived and designed the experiments. LK coordinated and performed the exercise experiment. BMcG, EH, LK and SE participated in the exercise experiment and collection of samples. SE performed the RNA extractions. JMacL provided the microarrays. BMcG and GOG performed the microarray and qRT-PCR experiments. SP was responsible for the annotation of the microarray. BMcG and SP analysed the data. DMacH assisted with manuscript preparation. BMcG and EH wrote the paper. All authors read and approved the final manuscript.

\section{Additional material}

\section{Additional file 1}

The relative distributions of gene ontology (GO) categories (Level 1) on the equine cDNA microarray. A list of all available human orthologues to equine genes was compared to a list of human orthologues of probes on the microarray using the Database for Annotation, Visualization and Integrated Discovery (DAVID) $[28,29]$ for functional clustering and overrepresentation analyses. The gene ontologies represented on the graph are: 1) gene expression, 2) metabolic process, 3) cellular process, 4) membrane-enclosed lumen, 5) macromolecular complex, 6) organelle part, 7) organelle, 8) cell part, 9) catalytic activity, 10) binding. Click here for file

[http://www.biomedcentral.com/content/supplementary/14712164-10-638-S1.PPT]

\section{Additional file 2}

Gene expression $a T_{1}$. Excel file containing GenBank IDs, $\log$ fold changes, unadjusted and adjusted p-values and annotation where available for all probes on the array.

Click here for file

[http://www.biomedcentral.com/content/supplementary/14712164-10-638-S2.XLS]

\section{Additional file 3}

Gene expression a $T_{2}$. Excel file containing GenBank IDs, log fold changes, unadjusted and adjusted p-values and annotation where available for all probes on the array.

Click here for file

[http://www.biomedcentral.com/content/supplementary/14712164-10-638-S3.XLS]

\section{Additional file 4}

Genes differentially expressed in KEGG pathways over-represented at $T_{2}$.

Click here for file

[http://www.biomedcentral.com/content/supplementary/1471-

2164-10-638-S4.XLS]

\section{Additional file 5}

Equine oligonucleotide primers used for real time qRT-PCR.

Click here for file

[http://www.biomedcentral.com/content/supplementary/1471-

2164-10-638-S5.XLS]

\section{Acknowledgements}

The authors thank Mr P.J. Rothwell and Mr G. Burke for access to horses. We thank the University Veterinary Hospital yard staff for assistance with exercise experiments. We thank Dr J.A. Browne for helpful advice and assistance with the laboratory work. This work was financed by a Science Foundation Ireland President of Ireland Young Researcher Award (04-YII$\mathrm{B} 539)$ to $\mathrm{EH}$.

\section{References}

I. Poole DC: Current concepts of oxygen transport during exercise. Equine and Comparative Exercise Physiology 2004, I ( I):5-22.

2. Young LE, Marlin DJ, Deaton C, Brown-Feltner H, Roberts CA, Wood JL: Heart size estimated by echocardiography correlates with maximal oxygen uptake. Equine Vet J Suppl 2002:467-47I.

3. Guthrie AJ, Lund RJ: Thermoregulation. Base mechanisms and hyperthermia. Vet Clin North Am Equine Pract 1998, 14(1):45-59.

4. Gunn HM: Muscle, bone and fat proportions and muscle distribution of Thoroughbreds and other horses. Equine exercise physiology 2 Davis, ICEEP, CA 1987 1987:253-264.

5. Booth FW, Tseng BS, Fluck M, Carson JA: Molecular and cellular adaptation of muscle in response to physical training. Acta Physiol Scand 1998, 162(3):343-350.

6. Martineau LC, Gardiner PF: Insight into skeletal muscle mechanotransduction: MAPK activation is quantitatively related to tension. J Appl Physiol 200I, 9 I (2):693-702.

7. Sahlin K, Tonkonogi M, Soderlund K: Energy supply and muscle fatigue in humans. Acta Physiol Scand 1998, 162(3):261-266.

8. Pilegaard H, Ordway GA, Saltin B, Neufer PD: Transcriptional regulation of gene expression in human skeletal muscle during recovery from exercise. Am J Physiol Endocrinol Metab 2000, 279(4):E806-8I4.

9. Jeukendrup AE: Modulation of carbohydrate and fat utilization by diet, exercise and environment. Biochem Soc Trans 2003, 3 I (Pt 6): I270-1273.

10. Ji LL: Exercise-induced modulation of antioxidant defense. Ann N Y Acad Sci 2002, 959:82-92.

II. Green HI: Membrane excitability, weakness, and fatigue. Can J Appl Physiol 2004, 29(3):29l-307.

12. Richter EA, Derave W, Wojtaszewski JF: Glucose, exercise and insulin: emerging concepts. J Physiol 200I, 535(Pt 2):3I3-322.

13. Adhihetty PJ, Irrcher I, Joseph AM, Ljubicic V, Hood DA: Plasticity of skeletal muscle mitochondria in response to contractile activity. Exp Physiol 2003, 88(I):99-107.

14. Carter SL, Rennie C, Tarnopolsky MA: Substrate utilization during endurance exercise in men and women after endurance training. Am J Physiol Endocrinol Metab 200I, 280(6):E898-907.

15. Fluck M, Hoppeler H: Molecular basis of skeletal muscle plasticity--from gene to form and function. Rev Physiol Biochem Pharmacol 2003, I 46:159-216.

16. Booth FW, Baldwin KM: Muscle plasticity: energy demanding and supply processes. In Handbook of physiology Volume Chap 24. Issue Sect 12 Edited by: Rowell LB, Shepherd JT. Oxford University Press, New York; 1996: 1075-1 I 23. 
17. Hood DA: Invited Review: contractile activity-induced mitochondrial biogenesis in skeletal muscle. J Appl Physiol 200I, 90(3): II $137-1157$.

18. Neufer PD, Ordway GA, Hand GA, Shelton JM, Richardson JA, Benjamin IJ, Williams RS: Continuous contractile activity induces fiber type specific expression of HSP70 in skeletal muscle. Am J Physiol 1996, 27 I(6 Pt I):C1828-1837.

19. Mahoney DJ, Parise G, Melov S, Safdar A, Tarnopolsky MA: Analysis of global mRNA expression in human skeletal muscle during recovery from endurance exercise. FASEB J 2005, I (I I): |498-1500.

20. Hoppeler $\mathrm{H}$, Klossner S, Fluck $M$ : Gene expression in working skeletal muscle. Adv Exp Med Biol 2007, 6 I 8:245-254.

21. Gibala MJ, McGee SL, Garnham AP, Howlett KF, Snow RJ, Hargreaves $M$ : Brief intense interval exercise activates AMPK and p38 MAPK signaling and increases the expression of PGC-I alpha in human skeletal muscle. J Appl Physiol 2009, I 06(3):929-934.

22. Ikeda S, Kizaki T, Haga S, Ohno H, Takemasa T: Acute exercise induces biphasic increase in respiratory $\mathrm{mRNA}$ in skeletal muscle. Biochem Biophys Res Commun 2008, 368(2):323-328.

23. Louis E, Raue U, Yang Y, Jemiolo B, Trappe S: Time course of proteolytic, cytokine, and myostatin gene expression after acute exercise in human skeletal muscle. J Appl Physiol 2007, I03(5): |744-|75|.

24. Puntschart A, Wey E, Jostarndt K, Vogt M, Wittwer M, Widmer HR, Hoppeler $\mathrm{H}$, Billeter $\mathrm{R}$ : Expression of fos and jun genes in human skeletal muscle after exercise. Am J Physiol 1998, 274(I Pt I):CI29-I37.

25. Rose RJ: Poor performance: a clinical and physiological perspective. Proceedings of the nineteenth American College of Veterinary Internal Medicine Forum: 2001; Denver, Colo 2001:224-225.

26. Rose RJ, Hendrickson DK, Knight PK: Clinical exercise testing in the normal thoroughbred racehorse. Australian veterinary journal 1990, 67( I 0):345-348.

27. Woodie JB, Ducharme NG, Hackett RP, Erb HN, Mitchell LM, Soderholm LV: Can an external device prevent dorsal displacement of the soft palate during strenuous exercise? Equine veterinary journal 2005, 37(5):425-429.

28. Huang da W, Sherman BT, Lempicki RA: Systematic and integrative analysis of large gene lists using DAVID bioinformatics resources. Nat Protoc 2009, 4(I):44-57.

29. Dennis G, Sherman BT Jr, Hosack DA, Yang J, Gao W, Lane HC, Lempicki RA: DAVID: Database for Annotation, Visualization, and Integrated Discovery. Genome Biol 2003, 4(5):P3

30. Puntschart A, Vogt M, Widmer HR, Hoppeler H, Billeter R: Hsp70 expression in human skeletal muscle after exercise. Acta Physiol Scand 1996, I 57(4):4 I I-4I7

31. Simon P, Fehrenbach E, Niess AM: Regulation of immediate early gene expression by exercise: short cuts for the adaptation of immune function. Exerc Immunol Rev 2006, I 2: I | 2- I3 |.

32. McArdle F, Spiers S, Aldemir H, Vasilaki A, Beaver A, Iwanejko L, McArdle A, Jackson MJ: Preconditioning of skeletal muscle against contraction-induced damage: the role of adaptations to oxidants in mice. J Physiol 2004, 56 I (Pt I):233-244.

33. Broome CS, Kayani AC, Palomero J, Dillmann WH, Mestril R, Jackson MJ, McArdle A: Effect of lifelong overexpression of HSP70 in skeletal muscle on age-related oxidative stress and adaptation after nondamaging contractile activity. FASEB J 2006, 20(9):|549-|55|.

34. Marber MS, Mestril R, Chi SH, Sayen MR, Yellon DM, Dillmann WH: Overexpression of the rat inducible 70-kD heat stress protein in a transgenic mouse increases the resistance of the heart to ischemic injury. J Clin Invest 1995, 95(4): | 446- | 456.

35. Gething MJ, Sambrook J: Protein folding in the cell. Nature 1992 355(6355):33-45

36. Tupling AR, Gramolini AO, Duhamel TA, Kondo H, Asahi M, Tsuchiya SC, Borrelli MJ, Lepock JR, Otsu K, Hori M, et al: HSP70 binds to the fast-twitch skeletal muscle sarco(endo)plasmic reticulum Ca2+ -ATPase (SERCA I a) and prevents thermal inactivation. I Biol Chem 2004, 279(50):52382-52389.

37. Senf SM, Dodd SL, McClung JM, Judge AR: Hsp70 overexpression inhibits NF-kappaB and Foxo3a transcriptional activities and prevents skeletal muscle atrophy. FASEB I 2008, 22(I I):3836-3845.
38. Saleh A, Srinivasula SM, Balkir L, Robbins PD, Alnemri ES: Negative regulation of the Apaf-I apoptosome by Hsp70. Nat Cell Biol 2000, 2(8):476-483.

39. Moresi V, Garcia-Alvarez G, Pristera A, Rizzuto E, Albertini MC, Rocchi M, Marazzi G, Sassoon D, Adamo S, Coletti D: Modulation of caspase activity regulates skeletal muscle regeneration and function in response to vasopressin and tumor necrosis factor. PLOS ONE 2009, 4(5):e5570.

40. Yun $\mathrm{H}$, Lee $\mathrm{M}$, Kim SS, Ha J: Glucose deprivation increases mRNA stability of vascular endothelial growth factor through activation of AMP-activated protein kinase in DUI45 prostate carcinoma. I Biol Chem 2005 280( I I):9963-9972.

4I. Minchenko O, Opentanova I, Minchenko D, Ogura T, Esumi H: Hypoxia induces transcription of 6-phosphofructo-2-kinase/ fructose-2,6-biphosphatase-4 gene via hypoxia-inducible factor-I alpha activation. FEBS Lett 2004, 576(I-2): | 4-20.

42. Van Schaftingen E, Jett MF, Hue L, Hers HG: Control of liver 6phosphofructokinase by fructose 2,6-bisphosphate and other effectors. Proc Natl Acad Sci USA I 98I, 78(6):3483-3486.

43. Eivers SS, McGivney BA, Fonseca RG, Machugh DE, Menson K, Park $\mathrm{SD}$, Rivero JL, Taylor CT, Katz LM, Hill EW: Alterations in oxidative gene expression in equine skeletal muscle following exercise and training. Physiol Genomics 2009 in press.

44. Wittwer M, Billeter R, Hoppeler H, Fluck M: Regulatory gene expression in skeletal muscle of highly endurance-trained humans. Acta Physiol Scand 2004, I 80(2):2 17-227.

45. Arden C, Hampson LJ, Huang GC, Shaw JA, Aldibbiat A, Holliman G Manas D, Khan S, Lange AJ, Agius L: A role for PFK-2/FBPase-2, as distinct from fructose 2,6-bisphosphate, in regulation of insulin secretion in pancreatic beta-cells. Biochem J 2008 , 4I I(I):4I-5I

46. Jiao H, Kaaman M, Dungner E, Kere J, Arner P, Dahlman I: Association analysis of positional obesity candidate genes based on integrated data from transcriptomics and linkage analysis. Int J Obes (Lond) 2008, 32(5):816-825.

47. Obach $M$, Navarro-Sabate A, Caro J, Kong X, Duran J, Gomez $M$ Perales JC, Ventura F, Rosa JL, Bartrons R: 6-Phosphofructo-2kinase (pfkfb3) gene promoter contains hypoxia-inducible factor-I binding sites necessary for transactivation in response to hypoxia. J Biol Chem 2004, 279(5 I):53562-53570.

48. Wu Z, Huang X, Feng Y, Handschin C, Gullicksen PS, Bare O, Labow $M$, Spiegelman B, Stevenson SC: Transducer of regulated CREBbinding proteins (TORCs) induce PGC-I alpha transcription and mitochondrial biogenesis in muscle cells. Proc Natl Acad Sci USA 2006, I03(39): |4379-|4384.

49. Liu Y, Dentin R, Chen D, Hedrick S, Ravnskjaer K, Schenk S, Milne J, Meyers DJ, Cole P, Yates ], et al.: A fasting inducible switch modulates gluconeogenesis via activator/coactivator exchange. Nature 2008, 456(7219):269-273.

50. Price NT, Jackson VN, Halestrap AP: Cloning and sequencing of four new mammalian monocarboxylate transporter (MCT) homologues confirms the existence of a transporter family with an ancient past. Biochem J 1998, 329(Pt 2):321-328.

51. Snow DH, Guy PS: Muscle fibre type composition of a number of limb muscles in different types of horse. Res Vet Sci 1980, 28(2): | $37-\mid 44$.

52. Koho NM, Hyyppa S, Poso AR: Monocarboxylate transporters (MCT) as lactate carriers in equine muscle and red blood cells. Equine Vet J Suppl 2006:354-358

53. Wang Q, Morris ME: The role of monocarboxylate transporter $\mathbf{2}$ and 4 in the transport of gamma-hydroxybutyric acid in mammalian cells. Drug Metab Dispos 2007, 35(8): I 393- I 399.

54. Lyon RC, Johnston SM, Panopoulos A, Alzeer S, McGarvie G, Ellis EM: Enzymes involved in the metabolism of gamma-hydroxybutyrate in SH-SY5Y cells: identification of an iron-dependent alcohol dehydrogenase ADHFel. Chem Biol Interact 2009 , I 78( I-3):283-287.

55. Gu J, Orr N, Park SD, Katz LM, Sulimova G, MacHugh DE, Hill EW: A genome scan for positive selection in thoroughbred horses. PLOS ONE 2009, 4(6):e5767.

56. Al-Shahrour F, Arbiza L, Dopazo H, Huerta-Cepas J, Minguez P, Montaner D, Dopazo J: From genes to functional classes in the study of biological systems. BMC Bioinformatics 2007, 8: I | 4 . 
57. Dohm GL, Kasperek G], Tapscott EB, Beecher GR: Effect of exercise on synthesis and degradation of muscle protein. Biochem J 1980, I 88(I):255-262

58. Gautsch TA, Anthony JC, Kimball SR, Paul GL, Layman DK, Jefferson LS: Availability of elF4E regulates skeletal muscle protein synthesis during recovery from exercise. Am J Physiol 1998, 274(2 Pt I):C406-4I4.

59. Williamson DL, Kubica N, Kimball SR, Jefferson LS: Exerciseinduced alterations in extracellular signal-regulated kinase I/ 2 and mammalian target of rapamycin (mTOR) signalling to regulatory mechanisms of mRNA translation in mouse muscle. J Physiol 2006, 573(Pt 2):497-5I0.

60. Hunt CR, Parsian AJ, Goswami PC, Kozak CA: Characterization and expression of the mouse Hsc70 gene. Biochim Biophys Acto 1999, I 444(3):315-325.

6I. Humphries AD, Streimann IC, Stojanovski D, Johnston AJ, Yano M, Hoogenraad NJ, Ryan MT: Dissection of the mitochondrial import and assembly pathway for human Tom40. J Biol Chem 2005, 280( I 2): I I535-I I543.

62. Takahashi M, Chesley A, Freyssenet D, Hood DA: Contractile activity-induced adaptations in the mitochondrial protein import system. Am J Physiol I998, 274(5 Pt I):CI380-I387.

63. Bolender N, Sickmann A, Wagner R, Meisinger C, Pfanner N: Multiple pathways for sorting mitochondrial precursor proteins. EMBO Rep 2008, 9(I):42-49.

64. Neupert W, Herrmann JM: Translocation of proteins into mitochondria. Annu Rev Biochem 2007, 76:723-749.

65. Vissing K, Bayer ML, Overgaard K, Schjerling P, Raastad T: Heat shock protein translocation and expression response is attenuated in response to repeated eccentric exercise. Acta Physiol (Oxf) 2009, I 96(3):283-293.

66. Paulsen G, Vissing K, Kalhovde JM, Ugelstad I, Bayer ML, Kadi F, Schjerling P, Hallen J, Raastad T: Maximal eccentric exercise induces a rapid accumulation of small heat shock proteins on myofibrils and a delayed $\mathrm{HSP70}$ response in humans. Am J Physiol Regul Integr Comp Physiol 2007, 293(2):R844-853.

67. Ikeda $\mathrm{T}$, Abe $\mathrm{K}$, Ota A, Ikenoue $\mathrm{T}$ : Heat shock protein $\mathbf{7 0}$ and heat shock cognate protein $\mathbf{7 0}$ messenger ribonucleic acid induction in the brains, hearts, and livers of neonatal rats after hypoxic stress. Am J Obstet Gynecol 1999, I80(2 Pt I):457-46I.

68. Su CY, Chong KY, Edelstein K, Lille S, Khardori R, Lai CC: Constitutive hsp70 attenuates hydrogen peroxide-induced membrane lipid peroxidation. Biochem Biophys Res Commun 1999 265(2):279-284.

69. Ryhanen T, Hyttinen JM, Kopitz J, Rilla K, Kuusisto E, Mannermaa E, Viiri J, Holmberg Cl, Immonen I, Meri S, et al.: Crosstalk between Hsp70 molecular chaperone, lysosomes and proteasomes in autophagy-mediated proteolysis in human retinal pigment epithelial cells. J Cell Mol Med 2008 in press.

70. Vlahovich N, Schevzov G, Nair-Shaliker V, Ilkovski B, Artap ST, Joya JE, Kee AJ, North KN, Gunning PW, Hardeman EC: Tropomyosin 4 defines novel filaments in skeletal muscle associated with muscle remodelling/regeneration in normal and diseased muscle. Cell Motil Cytoskeleton 2008, 65(I):73-85.

7I. Klip A: The many ways to regulate glucose transporter 4. Appl Physiol Nutr Metab 2009, 34(3):481-487.

72. Boden G: Pathogenesis of type 2 diabetes. Insulin resistance. Endocrinol Metab Clin North Am 200I, 30(4):80I-8I5.

73. Reynolds THt, Bodine SC, Lawrence JC Jr: Control of Ser2448 phosphorylation in the mammalian target of rapamycin by insulin and skeletal muscle load. I Biol Chem 2002, 277(20): |7657-17662.

74. Wretman C, Lionikas A, Widegren U, Lannergren J, Westerblad H, Henriksson J: Effects of concentric and eccentric contractions on phosphorylation of MAPK(erk I/2) and MAPK(p38) in isolated rat skeletal muscle. J Physiol 200 I, 535(Pt I): I55-I64.

75. Johnson GL, Lapadat R: Mitogen-activated protein kinase pathways mediated by ERK, JNK, and p38 protein kinases. Science 2002, 298(5600):19||-|9|2.

76. Osorio-Fuentealba C, Valdes JA, Riquelme D, Hidalgo J, Hidalgo C, Carrasco MA: Hypoxia stimulates via separate pathways ERK phosphorylation and NF-kappaB activation in skeletal muscle cells in primary culture. J Appl Physiol 2009. 106(4): $1301-1310$.
77. Carson JA, Wei L: Integrin signaling's potential for mediating gene expression in hypertrophying skeletal muscle. J Appl Physiol 2000, 88(I):337-343.

78. Kuppuswamy D: Importance of integrin signaling in myocyte growth and survival. Circ Res 2002, 90( I 2): I 240-I242.

79. Fluck M, Mund SI, Schittny JC, Klossner S, Durieux AC, Giraud MN Mechano-regulated tenascin- $C$ orchestrates muscle repair. Proc Natl Acad Sci USA 2008, I 05(36): I 3662-I3667.

80. Klossner S, Durieux AC, Freyssenet D, Flueck M: Mechano-transduction to muscle protein synthesis is modulated by FAK. Eur J Appl Physiol 2009, I 06(3):389-398.

81. Spangenburg EE: Changes in muscle mass with mechanical load: possible cellular mechanisms. Appl Physiol Nutr Metab 2009, 34(3):328-335.

82. Durieux AC, D'Antona G, Desplanches D, Freyssenet D, Klossner S, Bottinelli R, Fluck M: Focal adhesion kinase is a load-dependent governor of the slow contractile and oxidative muscle phenotype. J Physiol 2009, 587(Pt I4):3703-37I7.

83. Yang R, Amir J, Liu H, Chaqour B: Mechanical strain activates a program of genes functionally involved in paracrine signaling of angiogenesis. Physiol Genomics 2008, 36(I): I-I4

84. Saleem A, Adhihetty PJ, Hood DA: Role of p53 in mitochondrial biogenesis and apoptosis in skeletal muscle. Physiol Genomics 2009, 37(I):58-66

85. Matoba S, Kang JG, Patino WD, Wragg A, Boehm M, Gavrilova O, Hurley PJ, Bunz F, Hwang PM: p53 regulates mitochondrial respiration. Science 2006, 3 I 2(5780): I650-1653.

86. Irrcher I, Ljubicic V, Kirwan AF, Hood DA: AMP-activated protein kinase-regulated activation of the PGC-I alpha promoter in skeletal muscle cells. PLOS ONE 2008, 3(10):e36I4.

87. Boland LM, Drzewiecki MM: Polyunsaturated fatty acid modulation of voltage-gated ion channels. Cell Biochem Biophys 2008, 52(2):59-84.

88. Ispirlidis I, Fatouros IG, Jamurtas AZ, Nikolaidis MG, Michailidis I, Douroudos I, Margonis K, Chatzinikolaou A, Kalistratos E, Katrabasas I, et al:: Time-course of changes in inflammatory and performance responses following a soccer game. Clin J Sport Med 2008, | 8(5):423-43 |

89. Amantea D, Nappi G, Bernardi G, Bagetta G, Corasaniti MT: Postischemic brain damage: pathophysiology and role of inflammatory mediators. FEBS J 2009, 276(I): 13-26.

90. Zhang H, Gao P, Fukuda R, Kumar G, Krishnamachary B, Zeller KI, Dang CV, Semenza GL: HIF-I inhibits mitochondrial biogenesis and cellular respiration in VHL-deficient renal cell carcinoma by repression of C-MYC activity. Cancer Cell 2007, I I (5):407-420.

91. Kondo K, Klco J, Nakamura E, Lechpammer M, Kaelin WG Jr: Inhibition of HIF is necessary for tumor suppression by the von Hippel-Lindau protein. Cancer Cell 2002, I(3):237-246.

92. Tavaria M, Gabriele T, Kola I, Anderson RL: A hitchhiker's guide to the human Hsp70 family. Cell Stress Chaperones 1996 I(I):23-28.

93. Huang WJ, Xia LM, Zhu F, Huang B, Zhou C, Zhu HF, Wang B, Chen $B$, Lei P, Shen GX: Transcriptional upregulation of HSP70-2 by HIF-I in cancer cells in response to hypoxia. Int J Cancer 2009. I 24(2):298-305.

94. Ivanova AV, Ivanov SV, Danilkovitch-Miagkova A, Lerman MI: Regulation of STRAI3 by the von Hippel-Lindau tumor suppressor protein, hypoxia, and the UBC9/ubiquitin proteasome degradation pathway. J Biol Chem 200I, 276( I 8): I5306-I53I5.

95. Miyazaki K, Kawamoto T, Tanimoto K, Nishiyama M, Honda H, Kato $Y$ : Identification of functional hypoxia response elements in the promoter region of the DECI and DEC2 genes. J Biol Chem 2002, 277(49):470|4-4702।.

96. Means AR, Dedman JR: Calmodulin--an intracellular calcium receptor. Nature 1980, 285(5760):73-77.

97. Wright NT, Prosser BL, Varney KM, Zimmer DB, Schneider MF Weber DJ: SIOOAI and calmodulin compete for the same binding site on ryanodine receptor. J Biol Chem 2008, 283(39):26676-26683.

98. Jeyasingham MD, Artigues A, Nadeau OW, Carlson GM: Structural evidence for co-evolution of the regulation of contraction and energy production in skeletal muscle. J Mol Biol 2008 , 377(3):623-629. 
99. Lindholm A, Piehl K: Fibre composition, enzyme activity and concentrations of metabolites and electrolytes in muscles of standardbred horses. Acta Vet Scand 1974, I 5(3):287-309.

100. Dingboom EG, Dijkstra G, Enzerink E, van Oudheusden HC, Weijs WA: Postnatal muscle fibre composition of the gluteus medius muscle of Dutch Warmblood foals; maturation and the influence of exercise. Equine Vet J Suppl 1999:95-100.

101. MacLeod JN: Equine articular cartilage microarray abstract. Plant \& Animal Genome Conference XIII: 2005; San Diego, CA, USA 2005.

102. Coleman SJ, Gong G, Gaile DP, Chowdhary BP, Bailey E, Liu L, MacLeod JN: Evaluation of Compass as a comparative mapping tool for ESTs using horse radiation hybrid maps. Anim Genet 2007, 38(3):294-302.

103. Band MR, Olmstead C, Everts RE, Liu ZL, Lewin HA: A 3800 gene microarray for cattle functional genomics: comparison of gene expression in spleen, placenta, and brain. Anim Biotechnol 2002, I3(1):163-172.

104. Smit A, Hubley R, Green P: RepeatMasker Open-3.0. 1996.

105. Team RDC: R: A language and environment for statistical computing. Vienna, Austria: R Foundation for Statistical Computing; 2005.

106. Gentleman RC, Carey VJ, Bates DM, Bolstad B, Dettling M, Dudoit S, Ellis B, Gautier L, Ge Y, Gentry J, et al.: Bioconductor: open software development for computational biology and bioinformatics. Genome Biol 2004, 5( I0):R80.

107. Irizarry RA, Hobbs B, Collin F, Beazer-Barclay YD, Antonellis KJ, Scherf U, Speed TP: Exploration, normalization, and summaries of high density oligonucleotide array probe level data. Biostatistics 2003, 4(2):249-264.

108. Bolstad BM, Irizarry RA, Astrand M, Speed TP: A comparison of normalization methods for high density oligonucleotide array data based on variance and bias. Bioinformatics 2003, 19(2): 185-193.

109. Cleveland WS: Robust locally weighted regression and smoothing scatterplots. Journal of the American Statistical Association 1979, 74(368):829-836.

I I0. Smyth GK, Michaud J, Scott HS: Use of within-array replicate spots for assessing differential expression in microarray experiments. Bioinformatics 2005, 2 I (9):2067-2075.

III. Smyth GK: Linear models and empirical bayes methods for assessing differential expression in microarray experiments. Stat Appl Genet Mol Biol 2004, 3:Article3.

112. Benjamini Y, Hochberg Y: Controlling the false discovery rate a practical and powerful approach to multiple testing. JR Stat Soc Ser B-Methodol 1995, 57(I):289-300.

I 13. Hosack DA, Dennis G, Sherman BT Jr, Lane HC, Lempicki RA: Identifying biological themes within lists of genes with EASE. Genome Biol 2003, 4(1 0):R70.

I 4. Al-Shahrour F, Minguez P, Tarraga J, Montaner D, Alloza E, Vaquerizas JM, Conde L, Blaschke C, Vera J, Dopazo J: BABELOMICS: a systems biology perspective in the functional annotation of genome-scale experiments. Nucleic Acids Res 2006:W472-476.

1 15. Vandesompele J, De Preter K, Pattyn F, Poppe B, Van Roy N, De Paepe A, Speleman F: Accurate normalization of real-time quantitative RT-PCR data by geometric averaging of multiple internal control genes. Genome Biol 2002 3(7): RESEARCH0034.

116. Livak KJ, Schmittgen TD: Analysis of relative gene expression data using real-time quantitative PCR and the 2(-Delta Delta C(T)) Method. Methods 200I, 25(4):402-408.
Publish with BioMed Central and every scientist can read your work free of charge

"BioMed Central will be the most significant development for disseminating the results of biomedical research in our lifetime. "

Sir Paul Nurse, Cancer Research UK

Your research papers will be:

- available free of charge to the entire biomedical community

- peer reviewed and published immediately upon acceptance

- cited in PubMed and archived on PubMed Central

- yours - you keep the copyright
BioMedcentral 